\title{
8
}
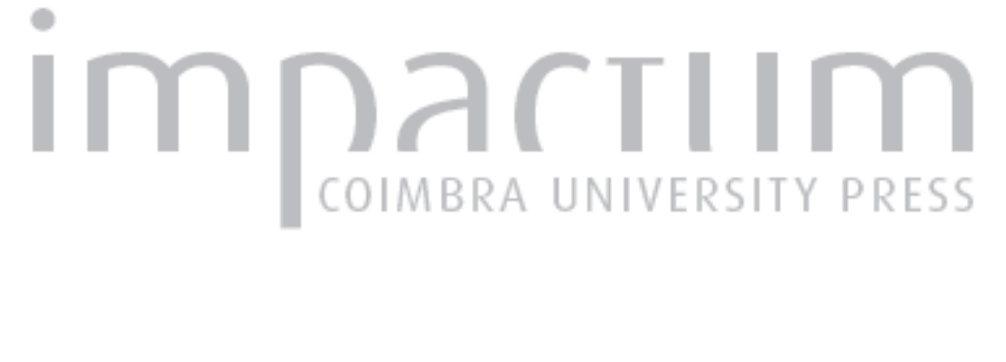

\section{A ilha de calor de Coimbra sob diferentes condições de tempo de verão}

Autor(es): Ganho, Nuno

Publicado por: Associação Portuguesa de Riscos, Prevenção e Segurança

URL persistente:

URI:http://hdl.handle.net/10316.2/40178

DOI:

DOl:https://doi.org/10.14195/1647-7723_2_4

Accessed : $\quad$ 26-Apr-2023 15:02:07

A navegação consulta e descarregamento dos títulos inseridos nas Bibliotecas Digitais UC Digitalis, UC Pombalina e UC Impactum, pressupõem a aceitação plena e sem reservas dos Termos e Condições de Uso destas Bibliotecas Digitais, disponíveis em https://digitalis.uc.pt/pt-pt/termos.

Conforme exposto nos referidos Termos e Condições de Uso, o descarregamento de títulos de acesso restrito requer uma licença válida de autorização devendo o utilizador aceder ao(s) documento(s) a partir de um endereço de IP da instituição detentora da supramencionada licença.

Ao utilizador é apenas permitido o descarregamento para uso pessoal, pelo que o emprego do(s) título(s) descarregado(s) para outro fim, designadamente comercial, carece de autorização do respetivo autor ou editor da obra.

Na medida em que todas as obras da UC Digitalis se encontram protegidas pelo Código do Direito de Autor e Direitos Conexos e demais legislação aplicável, toda a cópia, parcial ou total, deste documento, nos casos em que é legalmente admitida, deverá conter ou fazer-se acompanhar por este aviso.

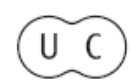




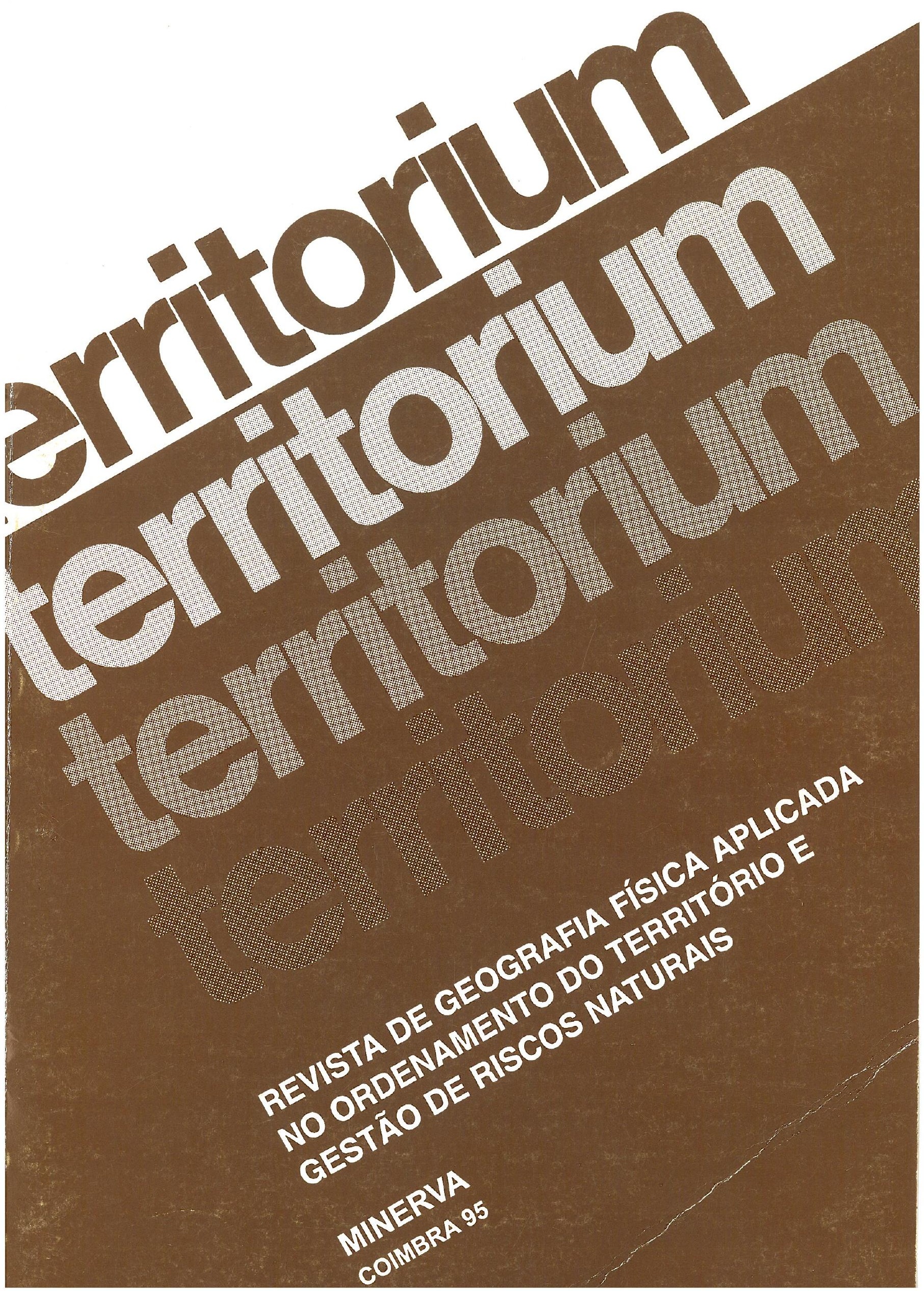




\title{
A ilha de calor de Coimbra sob diferentes condições de tempo de verão
}

\author{
Nuno Ganho
}

\begin{abstract}
Resumo:
Neste artigo apresentam-se os resultados preliminares da intensidade e fisionomia da ilha de calor de uma aglomeração urbana (Coimbra) da região centro de Portugal, de pequenas dimensões (100000 hab.) e de topografia acidentada, com diferentes condições de tempo de Verão, a partir de observações térmicas itinerantes, feitas de automóvel, em diferentes pontos da cidade.

Palavras chave:
\end{abstract}

Clima urbano. Ilha de calor. Condições de tempo. Coimbra.

Résumé:

Cet article établit une analyse préliminaire de l'intensité et de la physionomie de l'ilôt de chaleur d'une agglomération urbaine (Coimbra) de la région centre du Portugal, de petite taille (100000 habitants) et topographie tourmentée. Les données furent obtenues sous différentes conditions de temps d'été et à partir d'observations thérmiques itinérantes faites en voiture, en différents lieux de la ville.

Mots clés:

Climat urbain. Ilôt de chaleur. Conditions de temps. Coimbra.

\section{Abstract:}

This note concerns with the presentation of the preliminary analysis of both the intensity and the phisionomy of the heat island of a town (Coimbra) located in the center of Portugal, whose main features are its small proportions (100000 inhabitants) and rough topography.

The data, concerning different summer weather conditions, were registered by car in several different places of the town.

Key words:

Urban climate. Heat island. Weather conditions. Coimbra.

\section{Introdução}

As aglomerações urbanas, mesmo as de dimensões modestas, interferem significativamente nas características climáticas locais, criando, nomeadamente, o seu próprio campo de temperaturas. A criação de um clima urbano resulta da substituição da cobertura natural do solo por materiais como a pedra, o cimento e o asfalto, da geometria urbana característica e das alterações na composição da baixa atmosfera inerentes à concentração das actividades humanas, às quais se associa ainda a energia de origem antrópica. Os efeitos reflectem-se no balanço térmico local e conse-

\footnotetext{
* Assistente. Instituto de Estudos Geográficos, Faculdade de Letras, Universidade de Coimbra.
}

quentemente nas temperaturas, normalmente no sentido da criação de uma anomalia térmica positiva entre as aglomerações urbanas e os seus arredores. Este facto foi evidenciado pela primeira vez em 1918 por $\mathrm{L}$. HOWARD quando constatou que as temperaturas no interior de Londres são superiores às que se verificam na periferia da cidade (T. J. CHANDLER, 1962) . A esta anomalia térmica positiva G. MANLEY atribui pela primeira vez em 1958 a designação de ilha de calor (H. E. LANDSBERG, 1981). A ilha de calor resulta principalmente de uma maior ínércia térmica das áreas urbanas relativamente ao espaço rural envolvente, que consequentemente, durante a noite, arrefece mais rápida e intensamente do que a cidade. Assim, a ilha de calor é um fenómeno particularmente sensível durante a noite, sendo pouco marcada durante 
o dia ou, nalguns casos substituída por uma ilha de frescura. A sua intensidade e fisionomia, no entanto, variam de cidade para cidade, em função das características da morfologia urbana, da dimensão das aglomerações e de factores locais como a topografia. Variam também em função das características climáticas regionais e, para uma mesma cidade, de acordo com as condições de tempo.

O fenómeno da ilha de calor é uma das diversas manifestações da interferência da urbanização no clima local e a causa de alterações subsidiárias noutros parâmetros climáticos. Sobre esta temática existem centenas de artigos dedicados a aspectos específicos e a cidades em particular, mas escasseiam obras que sintetizem e apresentem uma visão de conjunto do tema, como as de H. E. LANDSBERG (1981), T. R. OKE (1987) ou G. ESCOURROU (1991).

A anomalia térmica positiva cidade/periferia urbana, quando se manifesta, cria circulações locais específicas, nomeadamente "brisas de campo" que penetram, com maior ou menor dificuldade no tecido urbano, de acordo com a sua organização espacial, com a sua morfologia e arquitectura urbanas e com o contex to topográfico da cidade. Altera também a estrutura térmica vertical das primeiras centenas de metros da atmosfera, contribuindo para a atenuação da intensidade de eventuais inversões térmicas locais, nuns casos, ou acentuando gradientes térmicos verticais, noutros casos, mas condicionando, de qualquer modo, os movimentos verticais da camada atmosférica por ela afectada, que eventualmente se repercutem nos níveis troposféricos suprajacentes, quando as condições meteorológicas, à escala sinóptica, assim o permitem.

Porque constitui um aumento local da temperatura, a ilha de calor aumenta localmente a capacidade higrométrica do ar o que, em conjugação com uma atenuação da evapotranspiração, inerente ao espaço construído, relativamente ao "campo" e consequente empobrecimento do teor em vapor de água na atmosfera, determina por vezes uma diminuição na humidade relativa.

Por tudo isto, directa ou indirectamente, o fenómeno ilha de calor urbano condiciona localmente outros aspectos climáticos, como a poluição atmosférica e o agravamento de determinadas patologias respiratórias específicas, a intensidade das precipitações, o que em episódios de carácter mais paroxístico reforça as suas consequências nefastas, os índices de conforto ou desconforto fisiológico, uma vez que neles entra sempre o binómio temperatura/humidade relativa, ou até os índices de risco de incêndio florestal nos espaços verdes urbanos.

Donde, a importância dos estudos do clima urbano em geral e da ilha de calor em particular, cujos resultados devem ser considerados em qualquer acção de planeamento urbano.
É no contexto de trabalhos integrados num projecto de investigação sobre o clima urbano de Coimbra (N. GANHO, 1992a, 1992b, 1994a, 1994b, ?) que se analisam agora os resultados preliminares sobre a magnitude e fisionomia da sua ilha de calor com diferentes condições de tempo de Verão ${ }^{(1)}$, à semelhança do que tem sido feito para inúmeras cidades mundiais (M.C.MORENO, 1990) e, nomeadamente em Espanha, para Madrid (A. LÓPEZ GÓMEZ et al, 1984, 1990, 1991), para Barcelona (C. CARRERAS et al, 1990) ou para Logroño (J. M. G. RUIZ et al., 1989) e em Portugal, para Lisboa (M. J. ALCOFORADO, 1986, 1988, 1992) e Porto (A. MONTEIRO, 1993).

\section{Localização, topografia e morfologia urbana de Coimbra}

A aglomeração urbana de Coimbra localiza-se na região centro de Portugal Continental, na fachada atlântica da Península Ibérica, a sensivelmente 40 $\mathrm{km}$ do litoral ocidental (fig. 1). Excluídos os lugares suburbanos, ocupa uma área superior a $20 \mathrm{~km}^{2} \mathrm{e}$ alberga uma população aproximada de 100000 habitantes.

O acidentado do relevo da área onde está implantada a cidade contribui para aumentar a diversidade climática local, especialmente nos seus aspectos térmicos.

Imediatamente a leste da cidade ergue-se um conjunto de colinas com orientação geral N-S, cujas altitudes ultrapassam os $500 \mathrm{~m}$ (Serras do Roxo e da Aveleira), que constitui o "Maciço Marginal de Coimbra" (P. BIROT, 1949). O desnivel entre a Serra do Roxo ( $510 \mathrm{~m})$ e os sectores mais baixos da cidade - que marginam o Mondego, o qual na área urbana corre a cotas pouco superiores a $20 \mathrm{~m}$ - é de quase $500 \mathrm{~m}$ numa distância horizontal de $5-6 \mathrm{~km}$.

Para ocidente, em direcção ao Atlântico, o relevo é constituído por colinas de baixa altitude e pequenos planaltos "num conjunto dominado pela planície aluvial de nível de base do Mondego e pelas suas penetrações em digitações nos vales afluentes" (F. REBELO, 1985, p. 194).

O sector Norte da cidade (fig. 2) ${ }^{(2)}$ ocupa uma colina dos contrafortes do Maciço Marginal que atinge os 190-200 metros na área do Tovim, 150-170 metros num retalho que se estende da Cumeada a

(1)Este texto corresponde a uma versão mais completa e actualizada do ponto de vista bibliográfico, de uma comunicação apresentada no / Encontro de Climatologia e Hidrologia Urbanas (N. GANHO, 1992c), que decorreu em Coimbra, em Setembro de 1992. A versāo original aguarda publicação, em castelhano, na revista Estudios Geográficos de Madrid (N. GANHO, ?).

(2) A mancha de povoamento urbano, que aparece representada nas figuras a sombreado, feita com base numa carta do Plano Director Municipal, esc. I:25000, datada de 1988, é hoje (1995) relativamente mais extensa. No entanto, optou-se, para já, por manter a mancha original da altura em que se procedeu à recolha dos dados e cartografia dos resultados (1991/92). 
Santo António dos Olivais e os 130 metros em Celas. Esta colina é limitada a Norte pelo encaixe do vale da Ribeira de Coselhas, profundo e de vertentes abruptas, e a Ocidente por vertentes escarpadas que "mergulham" em direcção ao Mondego.

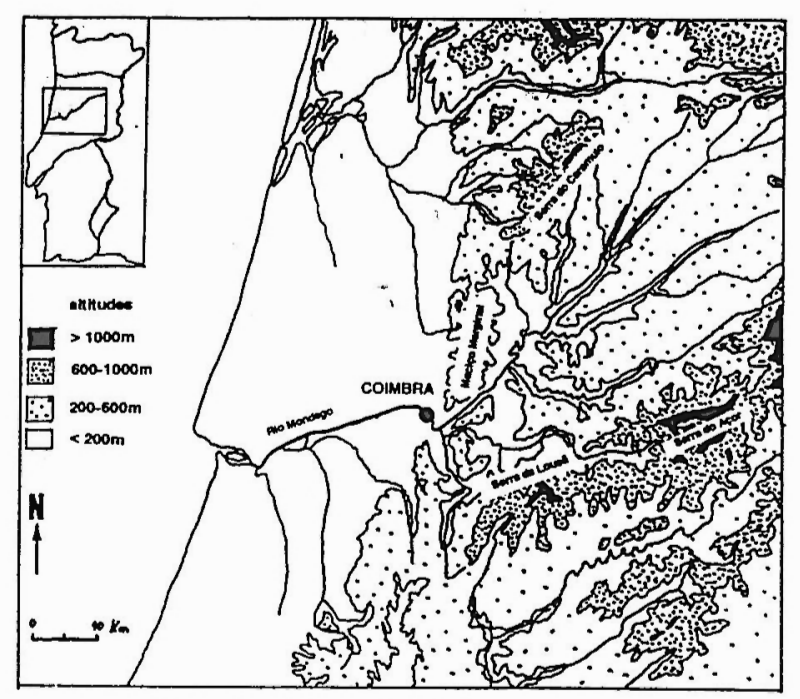

Fig. I - Localização de Coimbra no contexto morfológico regional.

O desenvolvimento de um vale em "cutilada", percorrido pela Av. Sá da Bandeira, em conjunto com a linha de água do Jardim Botânico, individualizam uma colina no topo da qual, à cota de 90 metros, se localizam os edifícios da Universidade. A bacia de recepção do vale da Av. Sá da Bandeira é ocupado em grande parte pelo Jardim de Santa Cruz. Este e o Jardim Botânico constituem os dois principais espaços verdes da cidade, perfeitamente integrados no tecido urbano.

Nas vertentes que a Ocidente marginam a colina da Universidade e no seu sector basal, aplanado, marginal ao Mondego, situam-se respectivamente a "Alta" e a "Baixa" coimbrãs.

O sector Sul da cidade ocupa uma forma deprimida em "ferradura" relacionada com um provável braço morto do Mondego (meandro da Arregaça). A base da forma situa-se à cota de 30-40 metros, onde se localizam os bairros de São José, Solum, Calhabé e Quinta da Nora. No seu centro desenvolve-se a Lomba da Arregaça, uma colina de dimensões modestas ( 80 metros no ponto mais elevado), em cuja metade Oriental, à cota de 50 metros, está implantado o Bairro Norton de Matos.

O meandro abandonado é limitado a Sul e a Leste por um conjunto de colinas que culminam a cotas de 120-140 metros, prolongando-se para Norte até ao Tovim-Santo António dos Olivais.
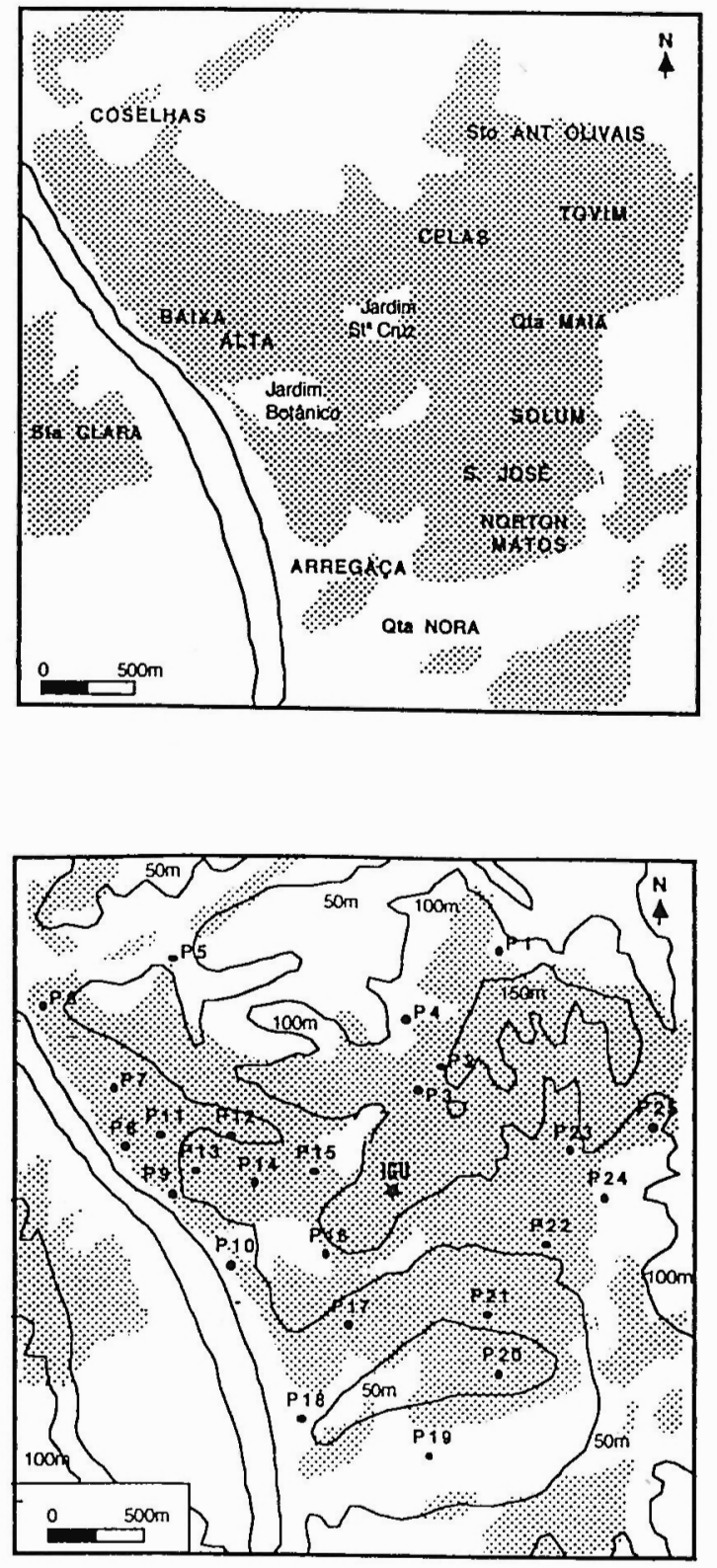

P1- Santo António dos Olivais, P2- R. Bernardo Albuquerque, P3Av. Calouste Gulbenkian, P4-Hospital da Universidade, P5-Estrada de Coselhas, P6- Av. Fernão de Magalhães (inicio), P7- Av. Fernão de Magalhães (Edifício Coimbra), P8- Av. Fernão de Magalhães (Largo das Olarias), P9- Largo da Portagem, P10- Parque Dr. Manuel Braga, P11- Praça 8 de Maio, P12- R. Olímpio Nicolau Fernandes, P13Largo da Sé velha, P14- Largo D. Dinis, P15- Praça da República, P16- Jardim Botânico, P17- R. do Brasil, P18- Arregaça, P19- Quinta da Nora, P20- Bairro Norton de Matos, P21- São José, P22- Solum, P23- Quinta da Maia, P24- Av. Elísio de Moura (Horto do Mondego), P25- Av. Elísio de Moura (cimo).

Fig. 2 - Toponímia, topografia e locais de observações itinerantes de temperatura 
No topo da vertente Norte do meandro, junto à escarpa do Penedo da Saudade, localiza-se a estação meteorológica do Instituto Geofísico da Universidade (IGU) ${ }^{(3)}$. Mais a Leste, desenvolvem-se uma bacia-vertente ocupada pela urbanização da Quinta da Maia e um vale que se estende da área da Solum ao Tovim, percorrido pela Av. Elísio de Moura.

Uma parte da aglomeração prolonga-se para as colinas e vertentes da margem esquerda do Mondego, em Santa Clara, a qual, por motivos de ordem prática não foi contemplada neste estudo.

Do ponto de vista da morfologia urbana, a "Alta" e a "Baixa", os núcleos mais antigos, distinguem-se nitidamente do resto da cidade. São constituídos por edifícios de 4 e 5 pisos, justapostos e dispostos ao longo de ruas estreitas, onde a radiação solar directa, especialmente no Inverno, dificilmente chega, mas onde, também, a ocultação do horizonte dificulta as perdas de energia por irradiação.

Contrastando com estes, nas áreas de construção recente proliferam, dispostos ao longo de ruas largas, edifícios modernos de dimensões variáveis, atingindo até 8 pisos em Celas, Quinta da Nora, Lomba da Arregaça ou Quinta da Maia, 10 a 12 pisos na Solum e na Arregaça, ou até 14 a 20 pisos na Av. Elísio de Moura. No Bairro Norton de Matos predominam as habitaçōes individuais, por vezes rodeadas de pequenos jardins, assim como nas vertentes que marginam a Sul e a Leste o meandro da Arregaça ou nos arredores do Hospital da Universidade.

Nas restantes áreas da cidade o que se encontra mais frequentemente são edifícios de pequenas dimensões ( 3 a 5 pisos), dispostos ao longo de ruas cuja largura permite a circulação em duas faixas, a distância variável uns dos outros, mas nunca determinando uma grande ocultação do horizonte.

\section{Metodologia de obtenção, tratamento e re- presentação dos dados}

A rede de estações meteorológicas dos organismos oficiais, pelo seu afastamento espacial, raramente pode ser utilizada para estudos de clima local. A reduzida dimensão do espaço estudado exige o recurso a outros métodos de obtenção dos dados. Em Climatologia urbana o método mais acessível e adequado ao estudo da variação espacial dos fenómenos térmicos no "canopy-layer" ${ }^{(4)}$, consiste na medição das temperaturas em diferentes pontos da cidade, distribuídos ao

\footnotetext{
(3) Estação meteorológica pertencente à rede de estações oficiais do Instituto de Meteorologia, localizada a $141 \mathrm{~m}$ de altitude, no interior da mancha de povoamento urbano mas $100 \mathrm{~m}$ acima das áreas de maior ocupação do solo, o que a torna relativamente imune à influência directa da urbanização e, por isso, pouco representativa do clima urbano (N. GANHO, 1992a, p. 91).

(4) Camada da atmosfera entre o nível da rua e o topo dos edifícios.
}

longo de um percurso automóvel previamente definido. Este foi utilizado pela primeira vez em 1929, simultaneamente por W. SCHMIDT em Viena e por A. PEPPLER em Karlsruhe (R. GEIGER, 1980), e foi o que se utilizou neste trabalho.

As observações itinerantes decorreram ao longo do Verão de 1991, sob diferentes condições de tempo, incidindo especialmente nos períodos do meio da tarde (observações diurnas), durante a madrugada e 3 a 4 horas após o pôr-do-sol (observações nocturnas), aqueles em que é suposto que se verifiquem, respectivamente, as temperaturas máximas, as temperaturas mínimas e os maiores contrastes térmicos entre a aglomeração urbana e os arredores.

Na obtenção dos dados utilizou-se um termómetro digital devidamente aferido pelo do abrigo do IGU que funcionou como estação de referência. Para proteger o elemento sensível da radiação improvisou-se um "abrigo". Utilizou-se uma caixa de cartão grosso, de $20 \times 20 \times 20 \mathrm{~cm}$, de côr branca, à qual se retirou o fundo e se fizeram cortes longitudinais nas faces laterais. A sonda era fixada no interior do "abrigo" $e$ este, por sua vez, era fixadoà parte lateral do automóvel a $1,5 \mathrm{~m}$ do solo. A ventilação era assegurada pelo movimento do veículo mantendo-se sempre a velocidade de andamento entre 30 e $40 \mathrm{Km} / \mathrm{h}$. Procedia-se à leitura no momento imediatamente a seguir à sua imobilização em cada um dos locais de observação.

Para além das temperaturas, sempre que se dispusesse de elementos para isso, anotavam-se a direcção e a intensidade do vento de acordo com a escala qualitativa de Beaufort, bem como outras informações pertinentes sobre o estado da atmosfera (existência de nevoeiro ou ocorrência de precipitação).

Aolongo dos percursos, em cada local de medição, a par da temperatura registava-se também a hora a que foi observada. Para eliminar (ou minorar) o efeito da variação da temperatura no tempo, calculou-se a diferença entre estas e as temperaturas observadas exactamente à mesma hora na estação meteorológica do IGU, determinadas a partir da curva do termógrafo. Obtêm-se deste modo temperaturas relativas ao IGU, de sinal positivo ou negativo consoante as temperaturas "reais" observadas nos respectivos locais eram superiores ou inferiores às que, no mesmo momento, se registavam na estação de referência.

As temperaturas relativas determinadas no decurso de cada campanha itinerante eram anotadas em mapas e a partir dos diferentes valores correspondentes a cada ponto, extrapolaram-se os resultados, construindo-se cartas de isotérmicas. O traçado das isotérmicas fez-se tendo em atenção a topografia local e a morfologia urbana.

As cartas acompanham-se de perfis topográficos transversais, com os respectivos perfis térmicos, obtidos pela junção, através de uma linha, de cada 
um dos pontos abrangidos por cada perfil topográfico. Deste modo, conseguem-se mais facilmente visualizar as relações entre a topografia, a morfologia urbana e o comportamento espacial da temperatura ao longo de determinados trajectos. Definiram-se três perfis topográficos (fig. 3), passando pelo maior número possível de pontos, contemplando diferentes contextos topográficos e urbanos ${ }^{(5)}$.

Com base nas cartas de isotérmicas e nos perfis térmicos analisa-se a repartição das temperaturas diurnas e nocturnas, na área urbana, com diferentes condições de tempo. Não se apresentam nem analisam os resultados de todos os percursos realizados, mas apenas os mais representativos dos diferentes padrões térmicos encontrados.

Este estudo sistematiza-se tendo como base uma tipologia de condições de tempo de Verão previamente definida (N. GANHO, 1991), em função das combinações dos elementos do tempo mais características e frequentes em Coimbra e das suas causas sinópticas.

A distinção fundamental faz-se entre condições de tempo perturbado, pouco frequentes nesta época do ano, e condições de tempo anticiclónico, que dominam largamente no período estival. Dentro dos tipos de tempo anticiclónicos, para as temperaturas diurnas, distinguem-se as raras situações de vento fraco, associadas a circulações continentais de Leste, das situações predominantes em que o vento, durante a tarde, no litoral ocidental de Portugal, sopra dos quadrantes de NW ("nortada"), como resultado do afeiçoamento do campo de pressão atmosférica ao contraste térmico que se estabelece entre a Península Ibérica, fortemente aquecida, e o Atlântico adjacente, mais fresco.

No contexto das condições de tempo anticiclónico, relativamente às temperaturas nocturnas, porque o vento, durante as noites de Verão, em Coimbra, é quase sempre fraco, a distinção faz-se sobretudo com base na nebulosidade e na humidade relativa. Assim contemplam-se situações de forte nebulosidade e situações sem nebulosidade e elevada humidade relativa, ambas muito frequentes e determinadas por circulações anticiclónicas fomentadoras de advecções de ar marítimo ao longo das regiões do litoral ocidental de Portugal, bem como situações sem nebulosidade e baixa humidade relativa, associadas a circulações continentais de Leste.

Contemplam-se também as situações, mais raras que as anteriores, em que, durante a noite, em Coimbra, o vento sopra de Leste com intensidade.

(5)Para a escolha do traçado dos perfis, muito contribuíram as valiosas sugestōes do Prof. Doutor Wielfried Endlicher quando, amavelmente, me acompanhou numa visita à área em estudo.

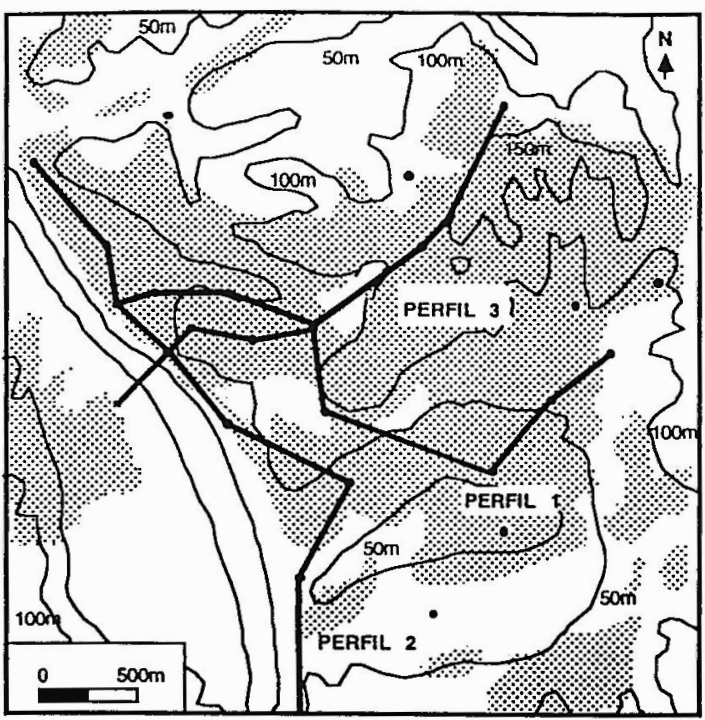

Fig. 3 - Traçado dos perfís térmicos.

\section{Percurso e locais de observação}

Os critérios que presidiram à escolha do percurso e dos locais de observação foram a topografia e a morfologia urbana. Pretendia-se seguir sempre o mesmo trajecto - aquele que minimizasse as distâncias, maximizando a área abrangida - e medir as temperaturas sempre nos mesmos locais.

A escolha dos locais fez-se em função da sua localização topográfica e posição no contexto da morfologia urbana, tentando cobrir a maior diversidade destes parâmetros, no menor intervalo de tempo, por forma a minimizar o efeito da variação temporal da temperatura. Chegou-se assim à definição de 25 pontos (fig. 2), disseminados pela cidade, que se passam a descrever sucintamente.

O percurso iniciava-se na Av. Elísio de Moura, mas só depois de uns minutos em andamento, para assegurar a ventilação e estabilização do termómetro, se procedia à primeira observação efectiva em Santo António dos Olivais (P1), na parte Nordeste da cidade, em posição topográfica sobreelevada, sem qualquer obstrução do horizonte.

A segunda observação fazia-se na Rua Bernardo Albuquerque (P2) junto ao BCG, num local ladeado por edifícios justapostos, de 2 a 3 pisos.

O terceiro ponto de observação contempla uma morfologia urbana bastante diferente: a Av. Calouste Gulbenkian (P3) em Celas, ampla e ladeada por edifícios novos de 8 andares.

Imediatamente a seguir, na mesma posição topográfica, mas num contex to urbano distinto, procedia-se a nova medição, frente à portaria principal do novo Hospital da Universidade (P4). Daí, pela Circular Interna, descia-se ao fundo do vale da Ribeira 
de Coselhas e efectuava-se a observação já na Estrada de Coselhas (P5), num local deprimido e de fraco coeficiente de ocupação do solo. A observação seguinte fazia-se na confluência da Estrada de Coselhas com o início da Av. Fernão de Magalhães (P6).

Na Av. Fernão de Magalhães, larga, ladeada por edifícios de 4 a 8 pisos, permanentemente com grande intensidade de tráfego, procedia-se a observações frente ao Edifício Coimbra (P7) e junto ao parque de estacionamento do Largo das Olarias (P8).

As medições seguintes faziam-se no Largo da Portagem (P9) e junto ao Parque Dr. Manuel Braga (P10).

No "coração" da "Baixa" procedia-se a medições na Rua Visconde da Luz junto à Praça 8 de Maio (P11) frente à Câmara Municipal e na Rua Olímpio Nicolau Fernandes (P12) junto ao Mercado Municipal. Estes dois locais conjugam um elevado grau de ocultação do horizonte - determinado por edifícios compactos ladeando ruas estreitas e pela posição na base das vertentes totalmente urbanizadas e de forte declive da parte terminal do vale da Av. Sá da Bandeira - com um trânsito intenso.

O local seguinte, no Largo da Sé Velha (P13), apresenta o mesmo tipo de morfologia urbana, mas situa-se já na "Alta" de Coimbra, portanto, num diferente contexto topográfico, tal como o subsequente, no Largo D. Dinis (P14), frente ao Departamento de Matemática, da Faculdade de Ciências e Tecnologia.

Também se faziam observações na Praça da República (P15) e na Alameda Dr. Júlio Henriques, junto ao Jardim Botânico (P16).

Os pontos seguintes situam-se no sector Sul da cidade, no "meandro da Arregaça", num contexto topográfico relativamente homogéneo, mas de grandes contrastes de intensidade de ocupação do solo e de morfologia urbana. Faziam-se medições na Rua do Brasil (P17), relativamente estreita, marginada por edifícios justapostos, de 4 a 8 pisos, e com intenso tráfego, em contraste com os locais seguintes, um na Av. Cónego Urbano Duarte na Arregaça (P18), junto ao Mondego e com fraco coeficiente de ocupação do solo, o outro na Quinta da Nora (P19) nas proximidades do Instituto Superior de Engenharia, com as mesmas características, mas mais afastado do rio.

Seguidamente, procedia-se a observações no Bairro Norton de Matos (P20), junto ao Centro Recreativo, em São José (P21), frente ao portão Sul do Estádio Municipal, local urbanizado mas sem grande densidade de construção a obstruir o horizonte, contrastando com a rotunda da Solum (P22), ladeada por edifícios de 12 andares mas significativamente afastados uns dos outros.

As medições seguintes faziam-se na base da bacia-vertente do bairro da Quinta da Maia (P23) e na parte terminal do vale da Av. Elísio de Moura, próximo do Horto do Mondego (P24), local com fraco coeficiente de ocupação do solo.

$O$ percurso terminava onde se tinha iniciado, quase no cimo da Av. Elísio de Moura (P25), próximo de edifícios de 14 a 20 andares, implantados na vertente do vale voltada a nascente. A vertente oposta, de menor declive, é ocupada por habitações individuais dispersas.

Por vezes faziam-se observações complementares noutros pontos (para além dos já referidos), incluídos no mesmo itinerário.

\section{Ilha de calor diurna}

\section{Condições de tempo perturbado}

O percurso efectuado na tarde do dia 5-6-91, reflecte bem a distribuição das temperaturas diurnas, na cidade, com condições de tempo perturbado de Verão (fig. 4 e 5). Durante o período de observações itinerantes vigoravam condições de tempo determinadas pela passagem de uma superfície frontal fria, em situação de margem anticiclónica, associada a uma perturbação centrada sobre a Irlanda e canalizada para a Península Ibérica pela circulação conjunta desta perturbação com o Anticiclone dos Açores ${ }^{(6)}$, localizado a SW do arquipélago. O céu estava encoberto, a humidade relativa elevada e o vento soprava de SW, fraco ou moderado, verificando-se a ocorrência de chuviscos esporádicos.

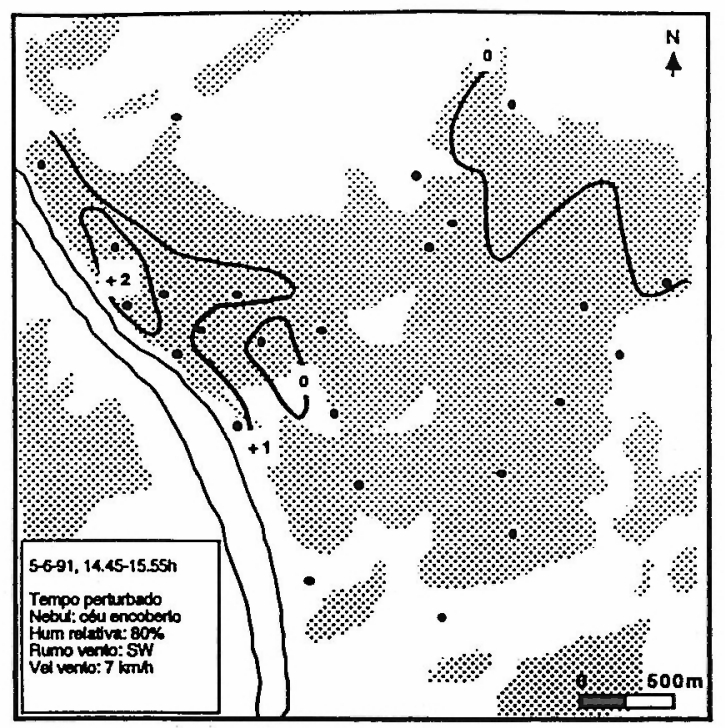

Fig. 4 - Temperaturas diurnas relativas ao IGU $\left({ }^{\circ} \mathrm{C}\right)$ com condições de tempo perturbado: o exemplo da tarde de 5 de Junho de 1991.

(6) A classificação dos anticiclones referidos ao longo do texto baseia-se na tipologia apresentada por C. RAMOS (1986, 1987). 
$\bullet \mathrm{C}$
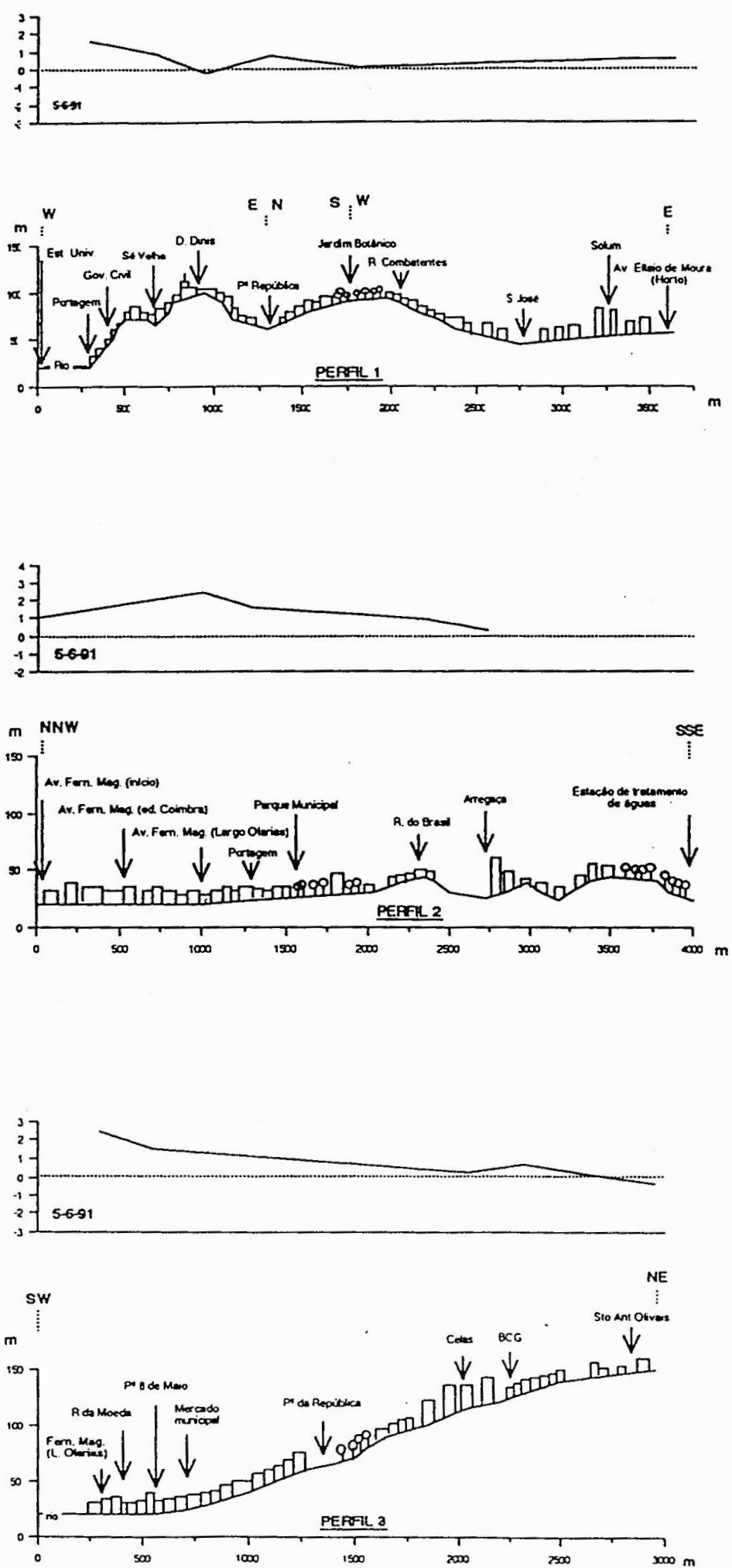

Fig. 5 - Perfis térmicos de temperaturas diurnas relativas ao IGU $\left({ }^{\circ} \mathrm{C}\right)$ com condiçôes de tempo perturbado.
Nestas condições, em grande parte da cidade a temperatura era igual ou ligeiramente superior à do IGU. Os locais mais frescos eram os mais elevados e consequentemente mais expostos ao vento, como o Tovim, Santo António dos Olivais e a área da Universidade, onde se observavam temperaturas um pouco inferiores às da estação de referência.

Em toda a área da "Baixa", desde o início da Av. Fernão de Magalhães ao Parque Dr. Manuel Braga, penetrando ao longo do vale da Av. Sá da Bandeira até ao início desta, a temperatura era superior à que se observava, no mesmo instante, no IGU, em $1^{\circ} \mathrm{C}$. O eixo mais quente correspondia à Av. Fernão de Magalhães, com temperaturas relativas de $+2^{\circ} \mathrm{C}$, por efeito de abrigo relativamente ao vento (soprava de $\mathrm{SW}$ ), determinado pela orientação da rua (NW-SE) e, provavelmente, em relação com a intensidade do trânsito.

\section{Condições de tempo anticiclónico com "nortada" moderada}

Os dias 11-6-91 e 22-6-91 representam condiçōes atmosféricas muito idênticas entre si, associadas a semelhantes condições sinópticas. O estado do tempo, em ambos os casos, era determinado por um fluxo de NW, canalizado pelo flanco oriental do Anticiclone dos Açores, pouco expandido para Norte e com o eixo orientado sensivelmente de W para E. O céu apresentava-se limpo ou pouco nublado, o vento soprava em regime de "nortada" moderada e a humidade relativa era, a estas horas, relativamente baixa.

Consequentemente, os padrões de repartição espacial das temperaturas, na área urbana, eram semelhantes.

Na tarde de 11-6-91 (fig. 6 e 10,11, 12), em todos os locais de observação, a temperatura era superior à que se observava na estação de referência em, pelo menos, $1^{\circ} \mathrm{C}$. As temperaturas mais elevadas ocorriam novamente ao longo da Av. Fernão de Magalhães com mais $3^{\circ} \mathrm{C}$ do que o IGU. Toda a área da "Baixa", parte terminal do vale de Coselhas, vale da Av. Sá da Bandeira até Celas, estendendo-se pela Rua do Brasil e São José, apresentavam temperaturas relativas entre $+2 \mathrm{e}+3^{\circ} \mathrm{C}$. Em grande parte do meandro da Arregaça, as temperaturas, embora um pouco superiores à do IGU, eram muito semelhantes entre os diversos 


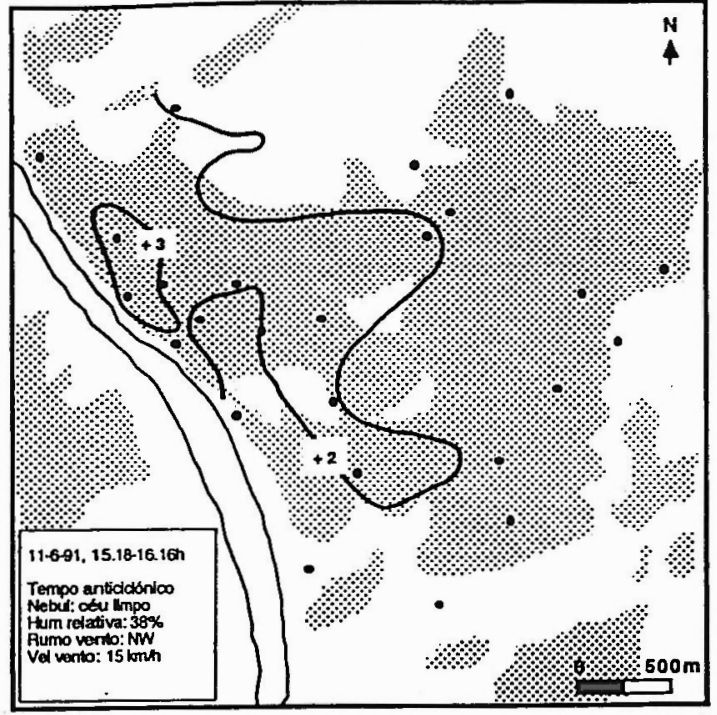

Fig. 6 - Temperaturas diurnas relativas ao IGU $\left({ }^{\circ} \mathrm{C}\right)$ com condições de tempo anticiclónico com "nortada": o exemplo da tarde de 11 de Junho de 1991.

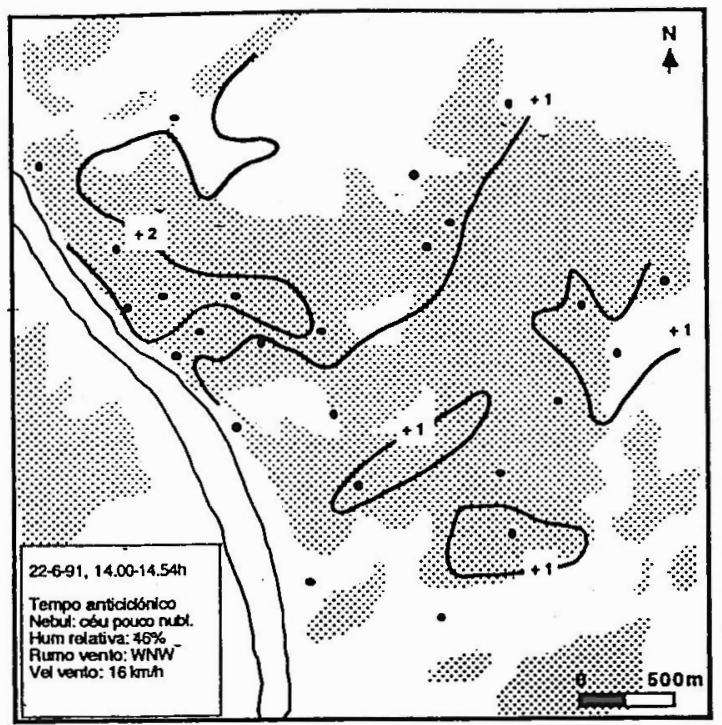

Fig. 7 - Temperaturas diurnas relativas ao IGU $\left({ }^{\circ} \mathrm{C}\right)$ com condiçōes de tempo anticiclónico com "nortada": o exemplo da tarde de 22 de Junho de 1991.

pontos, não sendo possível identificar, aqui, núcleos mais quentes.

Na tarde de 22-6-91 (fig. 7 e 10, 11, 12), todo o sector Norte da cidade encontrava-se, pelo menos $1{ }^{\circ} \mathrm{C}$, mais quente do que o IGU. As áreas mais quentes, com temperaturas relativas superiores a $+2^{\circ} \mathrm{C}$, eram o vale de Coselhas, a "Baixa" e o vale da Av. Sá da Bandeira. No entanto, entre diferentes pontos da cidade não se verificava um contraste térmico tão acentuado como no dia 11-6-91, em que ultrapassava os $3^{\circ} \mathrm{C}$. Mas as diferenças entre alguns locais do meandro da Arregaça eram ligeiramente maiores. Tanto o Bairro Norton de Matos, como a Quinta da Maia e a Av. Elísio de Moura, ou a vertente Norte do meandro, apresentavam temperaturas superiores ao IGU em $1^{\circ} \mathrm{C}$.

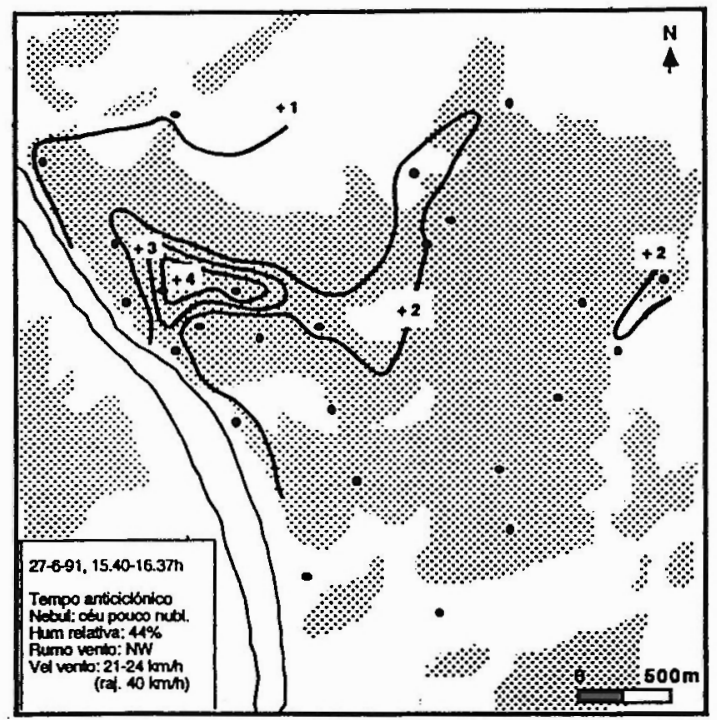

Fig. 8 - Temperaluras diurnas relativas ao $1 \mathrm{GU}\left({ }^{\circ} \mathrm{C}\right)$ com condições de tempo anticiclónico com "nortada" forte: o exemplo da tarde de 27 de Junho de 1991.

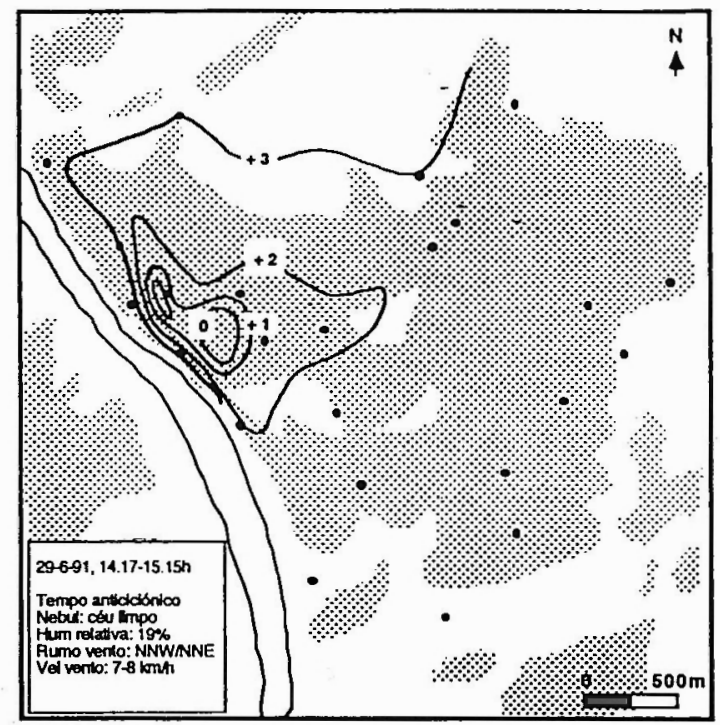

Fig. 9 - Temperaturas diurnas relativas ao IGU $\left({ }^{\circ} \mathrm{C}\right)$ com condições de tempo anticiclónico com vento fraco: o exemplo da tarde de 29 de Junho de 1991. 


\section{Condições de tempo anticiclónico com "nortada" forte}

A principal diferença entre estes dois dias referidos e a tarde do dia 27-6-91, reside na intensidade do vento. As condições de tempo eram determinadas pela circulação conjunta de uma crista do Anticiclone dos Açores, sobre o Golfo da Biscaia, com o habitual vale térmico ibérico.

Como reflexo do gradiente barométrico assim estabelecido ao longo do litoral Norte e. Centro de Portugal, em Coimbra, durante a tarde, o vento soprava de NW, moderado, com rajadas fortes, e a humidade relativa era baixa.

As diferenças de temperatura entre os diversos locais da aglomeração urbana (fig. 8 e $10,11,12$ ) eram superiores a $4^{\circ} \mathrm{C}$ e o seu dispositivo sugere uma importância acrescida do efeito de abrigo relativamente ao vento. Assim, os locais mais quentes, com mais $4^{\circ} \mathrm{C}$ do que o IGU, correspondiam à "Baixa" e, especialmente, ao vale da Av. Sáda Bandeira. Em todo o sector sul da cidade, mais desabrigado, as temperaturas relativas distribuíamse pelos diferentes locais de uma forma homogénea, com valores entre $+1 \mathrm{e}+2^{\circ} \mathrm{C}$. Só na Av. Elísio de Moura, protegida do vento pela vertente ocidental do vale, as temperaturas ultrapassavam em mais de $2^{\circ} \mathrm{C}$ a que se observava na estação de referência. Os locais mais frescos situavam-se no limite setentrional da aglomeração, mais exposto ao vento, onde as temperaturas relativas ficavam aquém de $+1^{\circ} \mathrm{C}$.

\section{Condições de tempo anticiclónico com vento fraco}

Nas raras situações estivais em que o vento sopra fraco durante a tarde, o dispositivo de repartição espacial das temperaturas alterase significativamente. $O$ percurso realizado a 29-6-91 evidencia bem este facto (fig. $9 \mathrm{e}$ $10,11,12$ ).

As condições de tempo eram determinadas por uma circulação fraca de Leste, canalizada por um vale térmico, com o eixo ao largo da costa portuguesa, criado no flanco Sul do Anticiclone dos Açores, estendendo-se em crista pelo Golfo da Biscaia em direcção ao Norte de África. O vento, fraco, inicialmente de NNW, a meio do percurso rodou para NNE e a humidade relativa era muito baixa.

As temperaturas mais elevadas (superiores a $+3^{\circ} \mathrm{C}$ ) observavam-se no limite Norte da cidade. Em todo o sector Sul, os contrastes
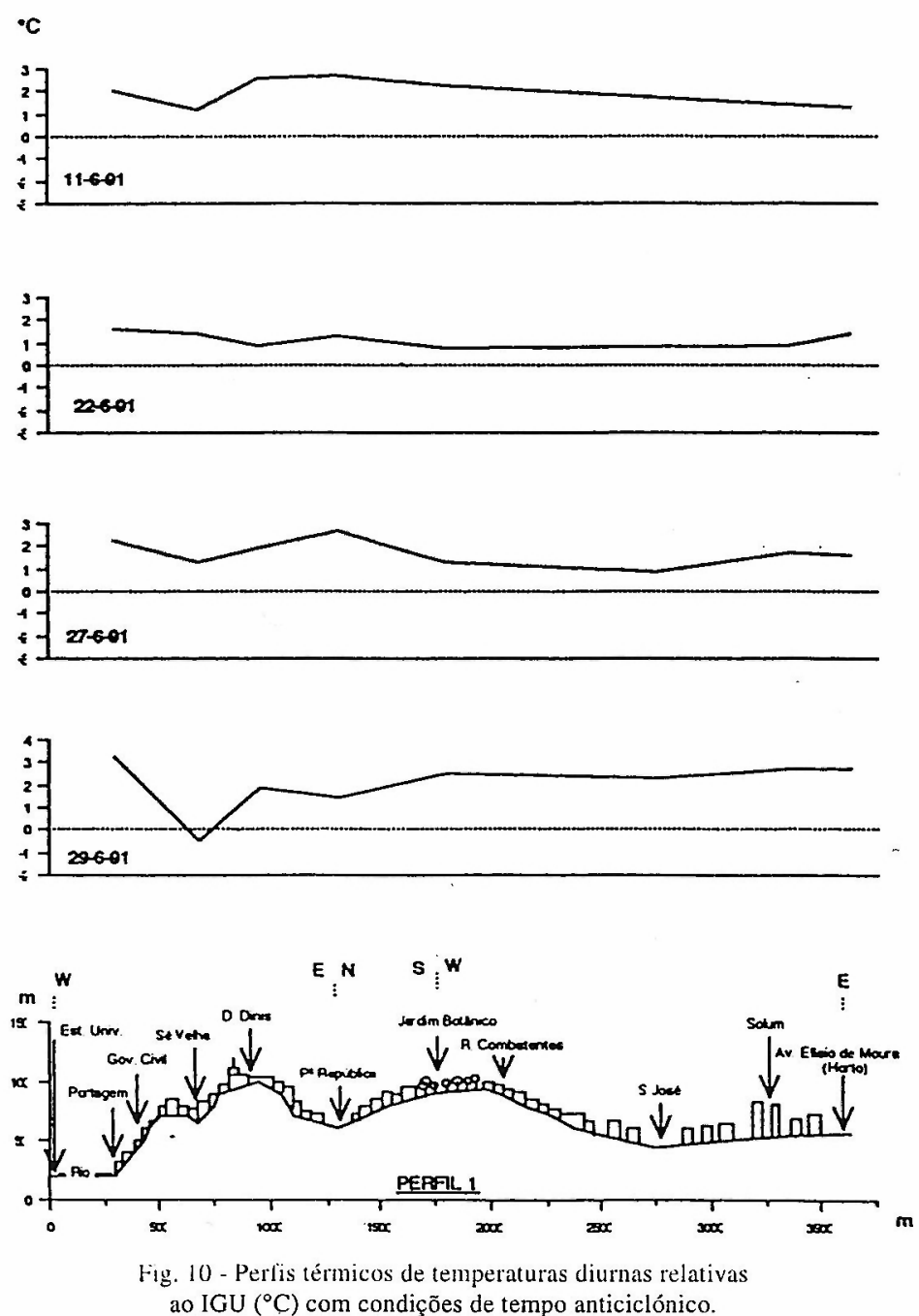

térmicos entre os diferentes locais eram pouco marcados e as temperaturas 2 a $3^{\circ} \mathrm{C}$ superiores à do IGU.

Os locais mais frescos correspondiam à "Baixa" e à "Alta", onde a temperatura era semelhante ou inferior à que se observava no IGU. Nas ruas mais estreitas, como a Rua da Moeda ou a Rua dos Coutinhos ${ }^{(7)}$, as temperaturas relativas ficavam aquém de $-1^{\circ} \mathrm{C}$.

Este padrão térmico original, que só se manifestou com condições de vento fraco, poderá ser interpretado como resultado da atenuação do aquecimento, por efeito de sombra, nas ruas estreitas da "cidade velha". Nas condições mais frequentes, em que durante a tarde se verificam ventos moderados dos quadrantes de NW, às consequências térmicas do efeito de sombra, sobre-

(7)Locais onde - para além dos 25 referidos - se fizeram observaçōes esporádicas, situados respectivamente na "Baixa" entre P8 e P11, e na "Alta" imediatamente antes de P13. 

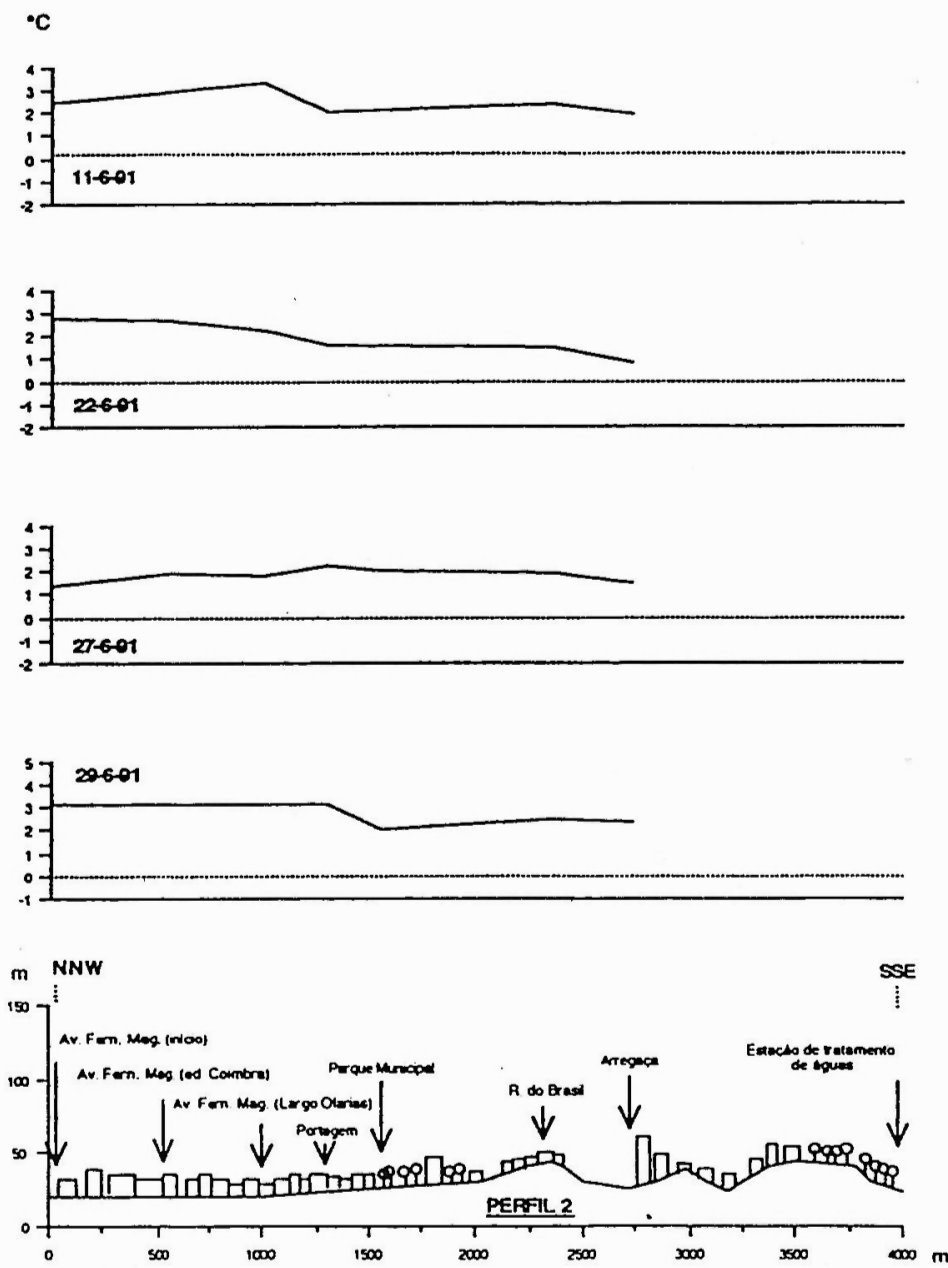

Fig. 11 - Perfis térmicos de temperaturas diurnas relativas ao IGU $\left({ }^{\circ} \mathrm{C}\right)$ com condições de tempo anticiclónico.

põem-se a acção do vento e o efeito de abrigo criado pela topografia e pela morfologia urbana, com as suas próprias consequências na distribuição das temperaturas.

\section{Ilha de calor nocturna}

\section{Condições de tempo perturbado}

Na madrugada de 7-6-91, com condições de tempo determinadas pela aproximação de uma superfície frontal fria associada a uma perturbação centrada a SW da Irlanda, o céu estava encoberto, a humidade relativa era muito elevada e o vento soprava fraco ou moderado, de $S$ no início do percurso, tendo rodado posteriormente para SW .

Como seria de esperar com tais condições de tempo, os contrastes térmicos entre diferentes pontos da cidade (fig. $13 \mathrm{e}$ 14) eram pouco marcados, pouco excedendo $1^{\circ} \mathrm{C}$. As temperaturas mais elevadas verificavam-se nas áreas mais baixas, com valores semelhantes entre locais com diferentes graus de urbanização. Toda a faixa desde o vale de Coselhas ao Largo da Portagem, abrangendo a "Baixa" e o vale da Av. Sá da Bandeira até à Praça da República, apresentava temperaturas superiores à do IGU, na ordem de $1^{\circ} \mathrm{C}$. Temperaturas idênticas observavam-se na área do meandro da Arregaça, nomeadamente na Rua do Brasil, na Quinta da Nora, e nos bairros Norton de Matos, São José e Solum. Nos locais mais elevados, desde a Universidade atéCelas, Santo António dos Olivais e Tovim, a temperatura era aproximadamente igual à que se observava na estação de referência.

\section{Condições de tempo anticiclónico com nebulosidade}

Nas frequentes situações estivais anticiclónicas, em que durante a noite e madrugada o céu permanece muito nublado, o padrão de repartição térmica espacial é semelhante ao que se verifica com tipo de tempo perturbado, como se constatou através das observações itinerantes realizadas na noite de 3-6-91.

O "anticiclone atlântico misto", centrado na área dos Açores, estendia-se em crista para as Ilhas Britânicas, canalizando para a fachada ocidental da Península Ibérica, através do seu flanco Leste, um fluxo meridiano, fomentando a entrada de ar marítimo, ao nível da baixa troposfera, no litoral Norte e Centro de Portugal (8). Consequentemente, em Coimbra, o céu estava encoberto, a humidade relativa elevada e o vento soprava de NW, fraco a moderado.

Não se verificavam grandes diferenças de temperatura entre os diferentes locais da aglomeração urbana (fig. 15 e 22, 23, 24). Os pontos mais quentes, com temperaturas relativas pouco superiores a $+1^{\circ} \mathrm{C}$, eram a "Baixa", o vale da Av. Sá da Bandeira incluindo a Praça da República, e a "Alta".

No sector Sul da cidade, as diferenças de temperatura com o IGU não chegavam a $+1^{\circ} \mathrm{C}$, excepto ao longo da Rua do Brasil onde ultrapassavam um pouco este valor, provavelmente por efeito de abrigo relativamente ao vento.

(8)Pelo facto de actualmente o IGU não proceder a sondagens aerológicas, todas as referências à estrutura verticalda troposfera que ao longo do tex to se fazem, baseiam-se em ilacçōes tiradas a partir dos resultados das observações aerológicas de Lisboa, publicadas nos Boletins Meteorológicos diários do INMG. 
Só em Celas e Santo António dos Olivais as temperaturas ficavam umas décimas de grau aquém da observada, no mesmo instante, na estação de referência.

\section{Condições de tempo anticiclónico, sem nebulosidade, com elevada humidade relativa}

Os percursos realizados nas madrugadas de 18, 24 e 27-6-91, ilustram a distribuição das temperaturas nocturnas sob condições de tempo anticiclónico, com céu limpo, vento fraco e elevada humidade relativa.

A 18-6-91, as condições meteorológicas eram determinadas por uma circulação de "retorno", canalizada conjuntamente por uma crista do Anticiclone dos Açores sobre o Golfo da Biscaia e um vale térmico sobre a Península Ibérica.

Tanto a 24 como a 27-6-91, Portugal estava sob influência de um fluxo de NW, expelido pelo flanco oriental do Anticiclone dos Açores, estendendo-se em crista em direcção à Península Ibérica.

Em qualquer destes dias verificava-se uma invasão de ar marítimo ao longo do litoral, mas a base da inversão térmica era suficientemente baixa para impedir a formação de nebulosidade. Nestas condições o céu estava limpo (embora a 27-6-91 se tenha encoberto ao fim da madrugada, muito depois de concluído o percurso de observação), a humidade relativa era elevada e o vento soprava fraco dos quadrantes de NW.

Como seria de esperar, atendendo à conjugação de céu limpo com vento fraco, os contrastes térmicos espaciais eram significativos, ultrapassando os $3^{\circ} \mathrm{C}$ entre diferentes pontos da cidade (fig.s 16,17, 18 e $22,23,24)$. Em função da drenagem e acumulação do ar frio, as temperaturas mais baixas verificavam-se nos locais deprimidos e pouco urbanizados. É o caso do vale de Coselhas e da Quinta da Nora, onde as temperaturas relativas eram negativas, atingindo ou ultrapassando os $-2^{\circ} \mathrm{C}$ a $18-6$ $91 \mathrm{e}$, respectivamente, os $-2 \mathrm{e}-1^{\circ} \mathrm{C}$ a $18 \mathrm{e}$ a 24-6-91. É também o caso da parte terminal do vale da Av. Elísio de Moura, com temperaturas relativas negativas (inferiores a $1{ }^{\circ} \mathrm{C}$ a 18 e a $24-6-91$, não atingindo este valor a 27-6-91).

As áreas mais quentes aparecem em idêntica situação topográfica, mas em relação com elevados coeficientes de ocupação do solo. A "Baixa", a "Alta", o vale da Av. Sá

\section{C}
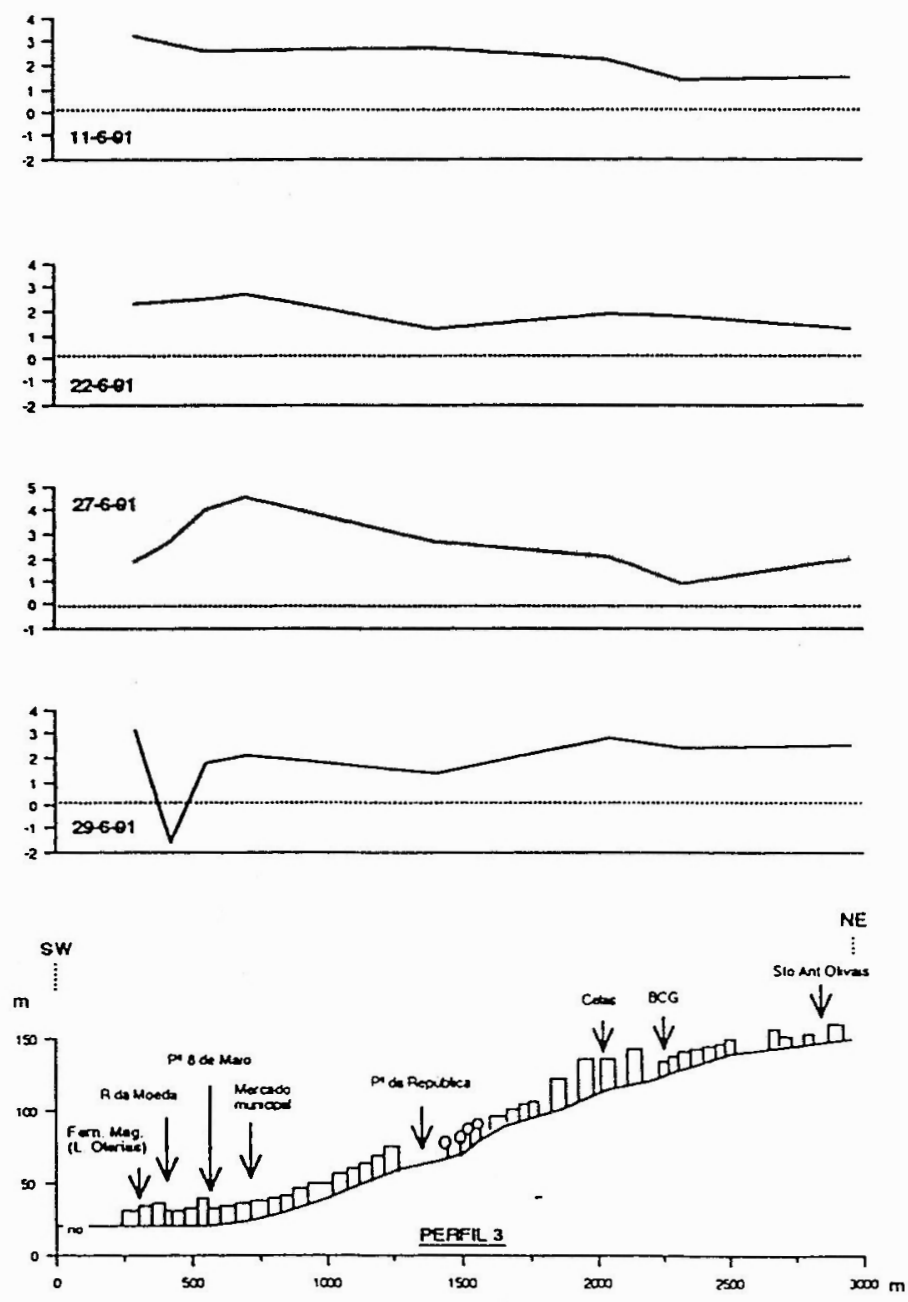

Fig. 12 - Perfis térmicos de temperaturas dilumas relativas ao $\operatorname{IGU}\left({ }^{\circ} \mathrm{C}\right)$ com condições de tempo anticiclónico.

da Bandeira e a Praça da República, apresentavam temperaturas superiores à do IGU, em $1^{\circ} \mathrm{C}$ a 18 e a 24-6-91, ultrapassando os $2^{\circ} \mathrm{C}$ de diferença a 27-06-91.

As áreas densamente urbanizadas do meandro da Arregaça, embora a cotas significativamente mais baixas do que o IGU, estavam sempre, pelo menos $1^{\circ} \mathrm{C}$ mais quentes do que este a 24 e 27-6-91, não chegando a tal valor a 18-6-91.

Em Celas e Santo António dos Olivais, as temperaturas eram idênticas à observada na estaçã̃o de referência, embora Santo António dos Olivais se encontrasse sempre umas décimas de grau abaixo do IGU.

Condições de tempo anticiclónico, sem nebulosidade, com baixa humidade relativa

Nas noites de 18-7-91 e de 29-6-91, circulações lentas de Leste, canalizadas respectivamente, pelo vale térmico ibérico com o eixo localizado ao largo da costa portuguesa, e pelo flanco Norte da depressão de origem térmica centrada sobre Lisboa, 


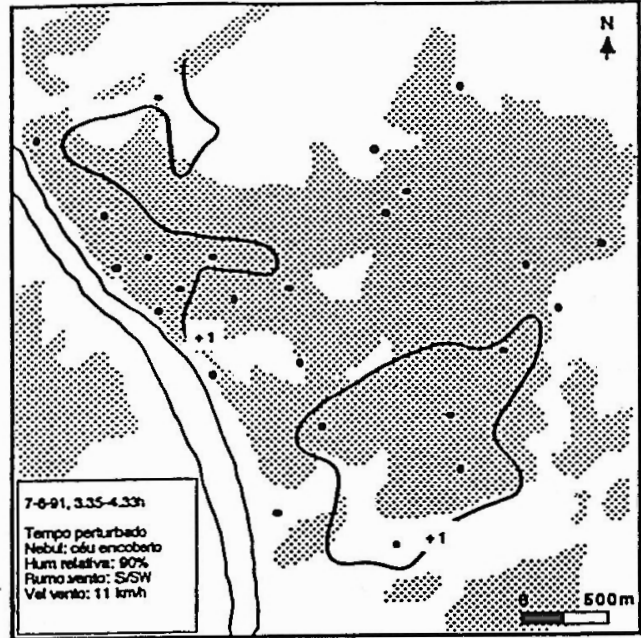

Fig. 13 - Temperaturas nocturnas relativas ao $\operatorname{IGU}\left({ }^{\circ} \mathrm{C}\right)$ com condiçôes de tempo perturbado: o exemplo da noite de 7 de Junho de 1991.

determinavam semelhantes condições de tempo em ambos os casos: céu limpo, humidade relativa baixa e vento fraco, de SW a 29-6-91 e de SSE a 18-7-91.

Relativamente às noites de 18, 24 e 27-6-91, a principal diferença reside na maior secura do ar. Os padrões de repartição das temperaturas não diferiam significativamente dos observados nessas noites, mas os contrastes térmicos espaciais são agora mais acentuados, ultrapassando $4^{\circ} \mathrm{C}$ a $18-7-91$ e $5^{\circ} \mathrm{Ca} 29$ -6-91 (fig.s 19, 20 e 22, 23, 24).

Os locais mais frescos surgem novamente em relação directa com a drenagem e acumulação de ar frio, nomeadamente no vale de Coselhas e na Arregaça, onde a temperatura relativa era inferior a $-3^{\circ} \mathrm{C}$, e no fundo do vale da Av. Elísio de Moura e na Quinta da Nora, onde ficava aquém de $-2^{\circ} \mathrm{C}$.

Nas áreas mais densamente urbanizadas do meandro da Arregaça, nomeadamente no Bairro Norton de Matos, em São José e na Solum, as temperaturas eram semelhantes à observada no IGU, mas $2 \mathrm{a} 3^{\circ} \mathrm{C}$ superiores às que, no mesmo momento, se registavam nas áreas envolventes, em igual contexto topográfico mas com menores coeficientes de ocupação do solo, evidenciando nitidamente a magnitude do efeito térmico deste factor.

Os locais mais quentes, com temperaturas relativas superiores $\mathrm{a}+1^{\circ} \mathrm{C}$, eram, novamente, a "Baixa" e a "Alta", mas também a área de
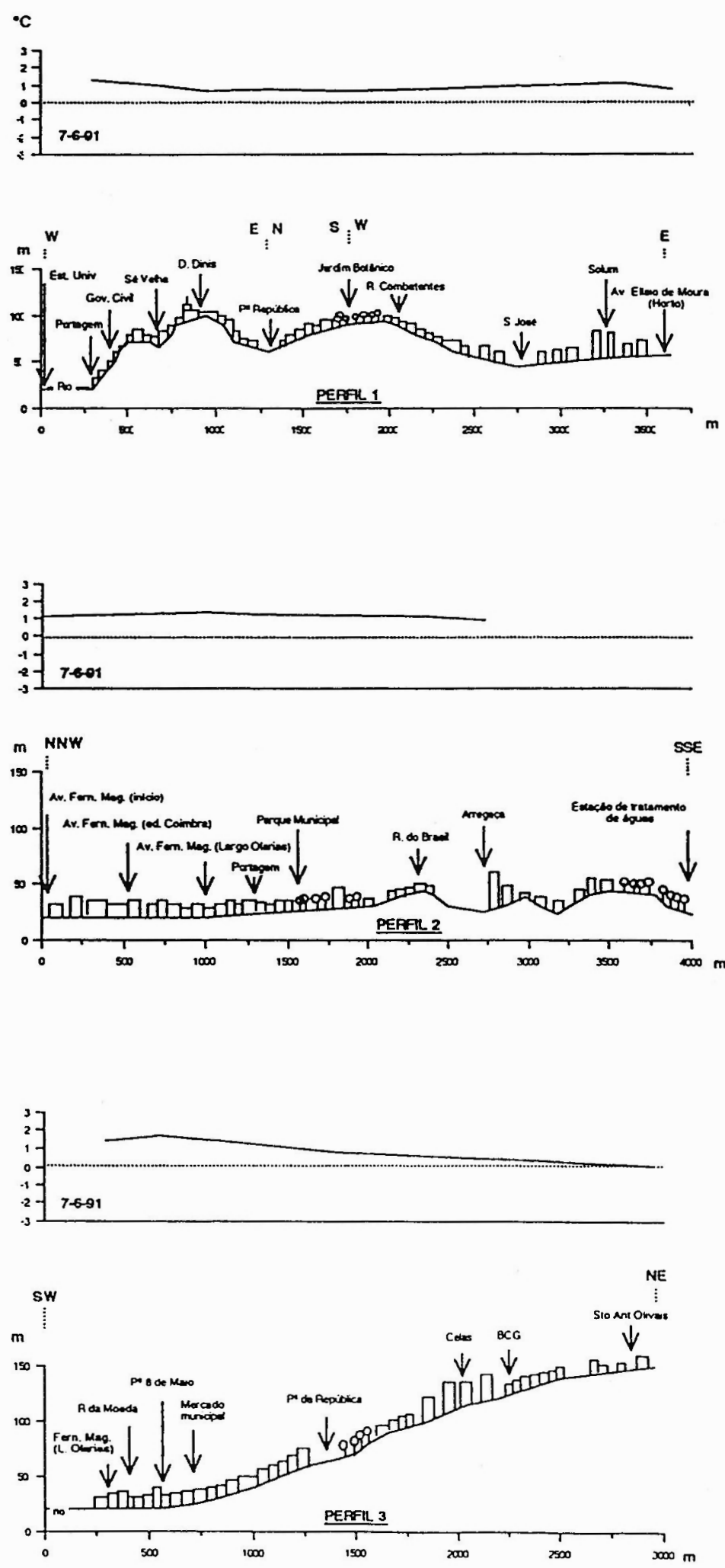

Fig. 14 - Perfis térmicos de temperaturas nocturnas relativas ao IGU $\left({ }^{\circ} \mathrm{C}\right)$ com condições de tempo perturbado. 


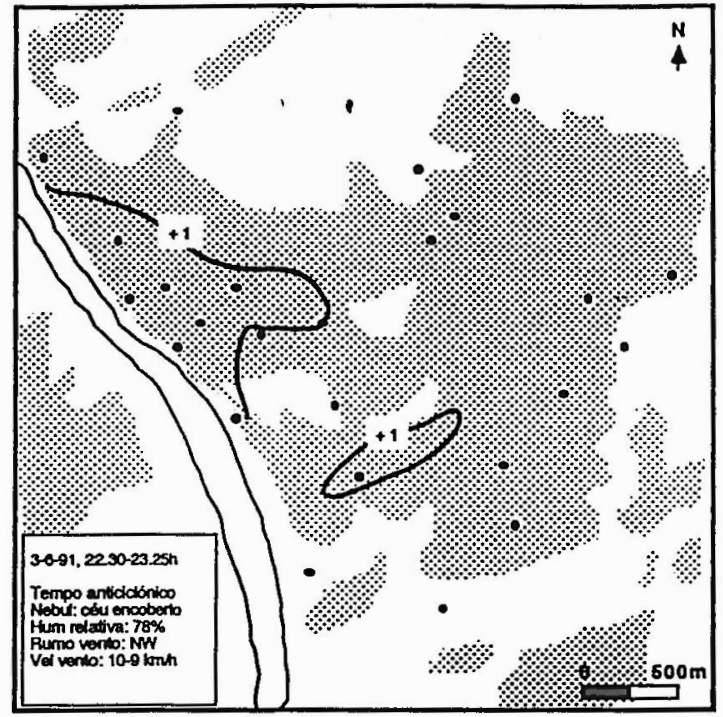

Fig, 15 - Temperaturas nocturnas relativas ao $I G U\left({ }^{\circ} \mathrm{C}\right) \mathrm{com}$ condições de tempo anticiclónico com céu encoberto: o exemplo da noite de 3 de Junho de 1991.

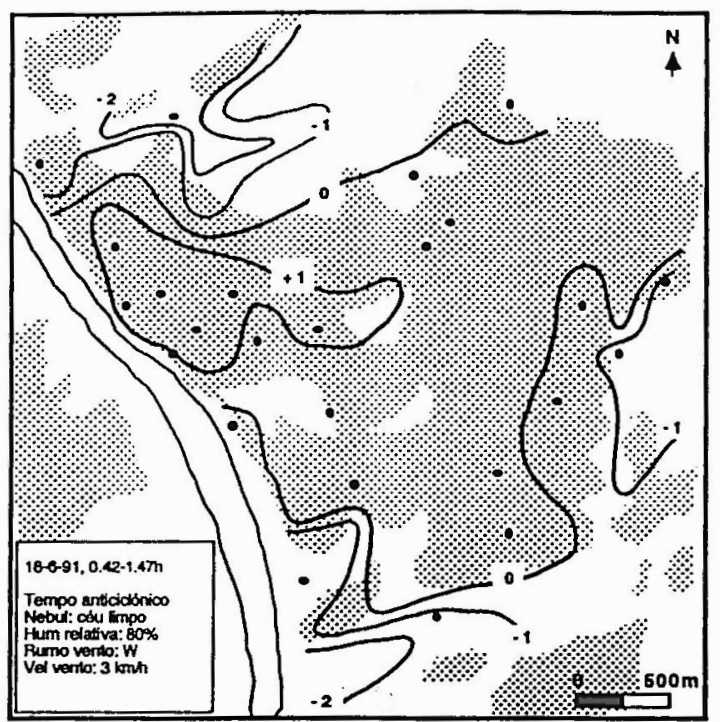

Fig. 16 - Temperaturas noctumas relativas ao $\operatorname{lGU}\left({ }^{\circ} \mathrm{C}\right) \mathrm{com}$ condições de tempo anticiclónico com céu limpo e elevada humidade relativa: o exemplo da noite de 18 de Junho de 1991 .

Celas, e de Santo António dos Olivais a 29-6-91, o que constitui a novidade relativamente às noites com semelhantes condições de tempo, mas com humidade relativa mais elevada. Observa-se também que, nas situações em que a humidade relativa nocturna é baixa, as temperaturas na Av. Fernão de Magalhães são semelhantes às observadas no IGU e que, nos espaços verdes do Parque Dr. Manuel Braga e do Jardim Botânico, a temperatura do ar era ligeiramante inferior à da estação de referência, factos que não se verificam nas noites de elevada humidade relativa.

\section{Condições de tempo anticiclónico com vento de \\ Leste}

O percurso realizado na madrugada de 30-6-91 evidencia um padrão de repartição térmica espacial curioso e original.

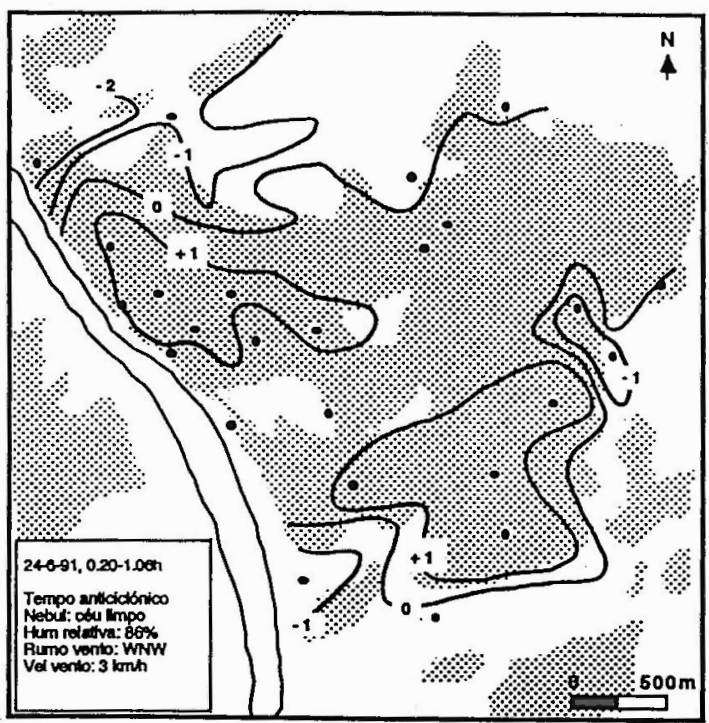

Fig. 17 - Temperaturas nocturnas relativas ao $1 G U\left({ }^{\circ} \mathrm{C}\right)$ com condições de tempo anticiclónico com céu limpo e elevada humidade relativa: o exemplo da noite de 24 de Junho de 1991.

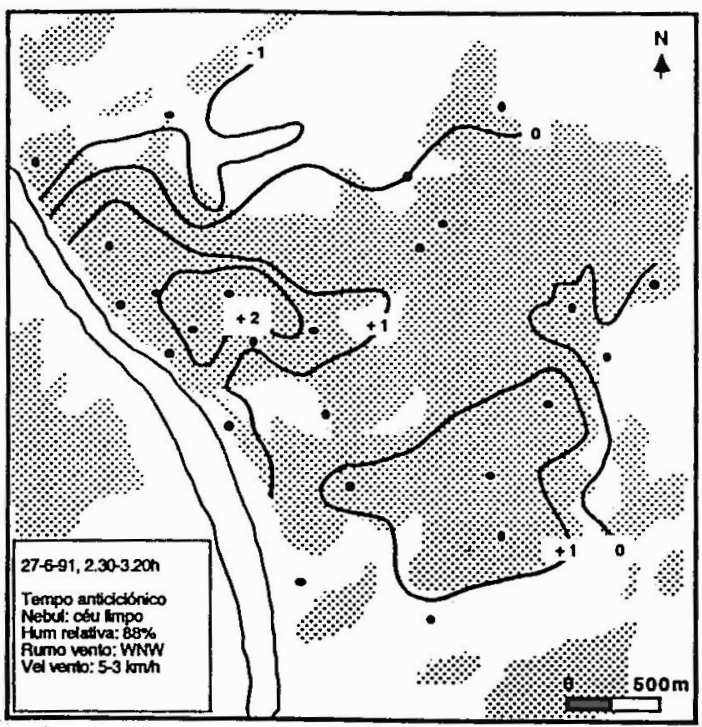

Fig. 18 - Temperaturas nocturnas relativas ao $\operatorname{IGU}\left({ }^{\circ} \mathrm{C}\right) \mathrm{com}$ condições de tempo anticiclónico com céu limpo e elevada humidade relativa: o exemplo da noite de 27 de Junho de 1991 
Verificavam-se condições de tempo determinadas por um fluxo de Leste generalizado a toda a fachada ocidental da Península Ibérica, associado ao flanco oriental de um vale térmico "desenhado" no bordo meridional do "anticiclone atlântico misto prolongandose pela Europa Ocidental" e pelo Norte de África.

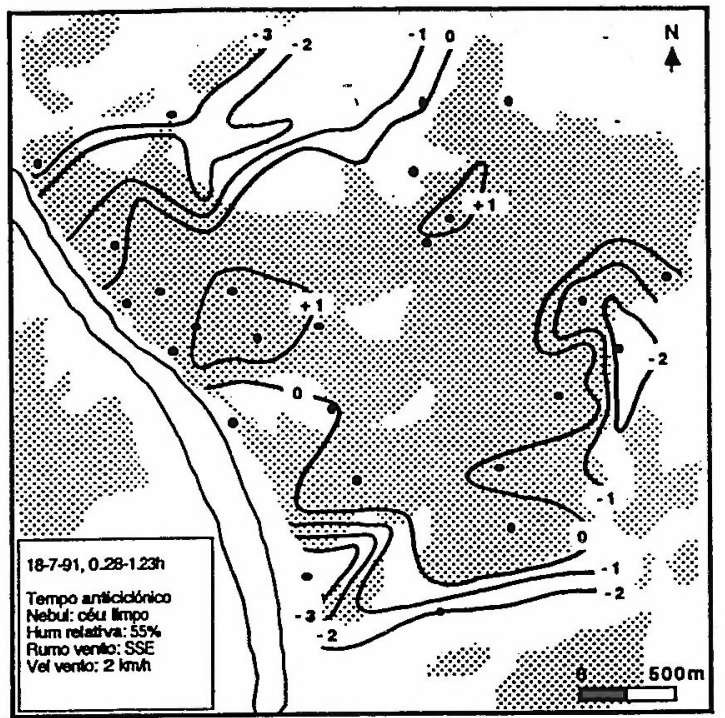

Fig. 19 - Temperaturas nocturnas relativas ao $\operatorname{IGU}\left({ }^{\circ} \mathrm{C}\right)$ com condições de tempo anticiclónico com céu limpo e ar seco: o exemplo da noite de 18 de Julho de 1991.

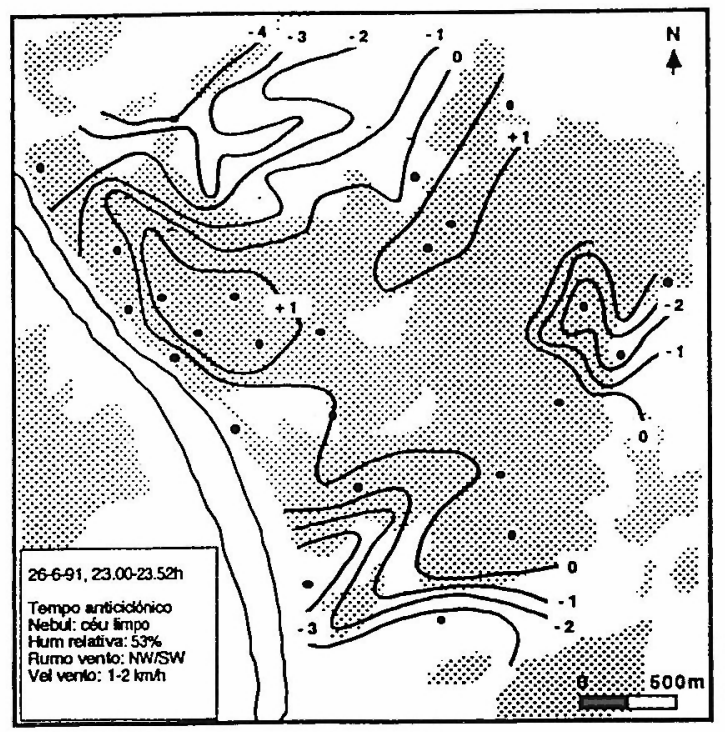

Fig. 20 - Temperaturas nocturnas relativas ao $\operatorname{IGU}\left({ }^{\circ} \mathrm{C}\right) \mathrm{com}$ condições de tempo anticiclónico com céu limpo e ar seco: o exemplo da noite de 29 de Junho de 1991.

(9)Na Av. Elísio de Moura e na Solum, locais onde soprava mais forte, as rajadas atingiam graus 6 a 7 da escala de Beaufort, o que aponta para velocidades de 40 a $60 \mathrm{~km} / \mathrm{h}$.

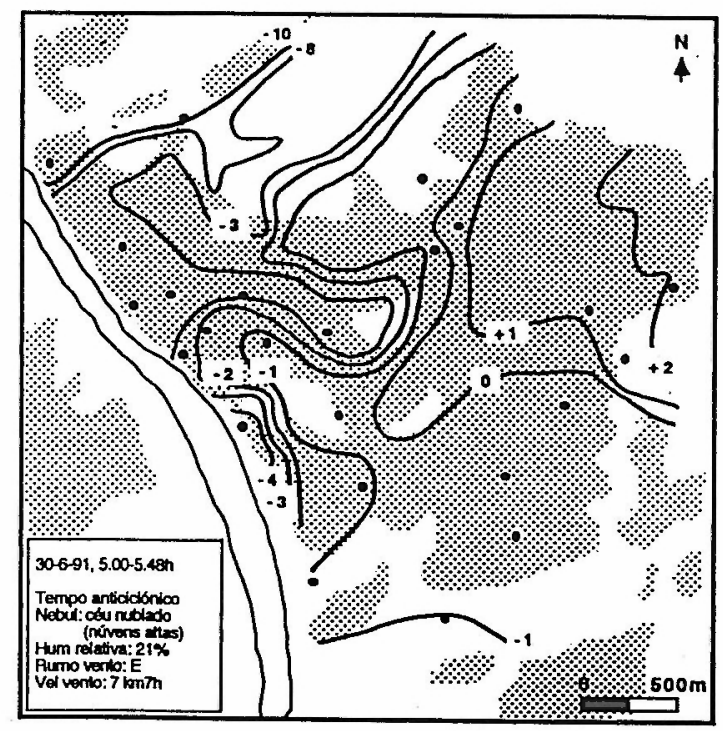

Fig. 21 - Temperaturas nocturnas relativas ao $\operatorname{IGU}\left({ }^{\circ} \mathrm{C}\right) \mathrm{com}$ condições de tempo anticiclónico com céu limpo, ar muito seco e vento de Leste: o exemplo da noite de 30 de Junho de 1991.

No IGU, o vento soprou fraco, com direcções variadas até às $00 \mathrm{~h}$ do dia 30-6-91. A partir desta hora começou a soprar moderado, predominantemente dos quadrantes de Leste, e a temperatura - que até aí tinharegistado uma descidaregular-subiu bruscamente. Durante o percurso de medição, realizado entre as $05 \mathrm{~h}$ e as $06 \mathrm{~h}$, o céu estava nublado com núvens altas - o que não interfere significativamente no balanço térmico nocturno (P. PÉDELABORDE, 1982 e R. GEIGER, 1980) - e a humidade relativa era muito baixa. O vento, de acordo com os registos do IGU, soprava moderado de E, mas, como se pôde verificar à medida que se iam percorrendo os diferentes pontos de observação, era muito variável entre diferentes locais. Em toda a faixa Leste e Sul da cidade, nomeadamente na Av. Elísio de Moura, Quinta da Maia, Solum, São José, Bairro Norton de Matos e Quinta da Nora, soprava moderado com rajadas fortes ${ }^{(9)}$. Pelo contrário, nos locais abrigados dos sectores setentrional e ocidental da aglomeração, como o vale de Coselhas, a "Baixa", o vale da Av. Sá da Bandeira e em toda a faixa marginal do Mondego até ao início da Rua do Brasil, o vento era fraco ou havia calma.

Esta original circulação local coincidia com uma não menos original repartição das temperaturas (fig. 21 e $22,23,24$ ).

Entre diferentes locais da cidade os contrastes térmicos atingiam $12^{\circ} \mathrm{C}(!)$. As temperaturas mais elevadas observavam-se ao longo da Av. Elísio de Moura, com mais $2^{\circ} \mathrm{C}$ do que na estação de referência. Os sectores Leste e Sul da cidade (todo o meandro da Arregaça, Santo António dos Olivais e Celas) e o 
topo da colina da Universidade apresentavam temperaturas superiores ou semelhantes à que se observava no IGU.

Os locais deprimidos dos sectores Norte e ocidental da aglomeração, estavam significativamente mais frescos, atingindo-se temperaturas relativas de $-10^{\circ} \mathrm{C}$ no vale de Coselhas e entre -3 e $-4^{\circ} \mathrm{C}$ na "Baixa", ao longo do vale da Av. Sá da Bandeira até à Praça da República, e na faixa ribeirinha entre o Parque Dr. Manuel Braga e a Rua do Brasil.

Nainterpretação destes resultados, admitese a hipótese de um aquecimento dos sectores Leste e Sul da cidade, por subsidência do ar ao longo das vertentes do Maciço Marginal, enquanto $o$ ar alojado nos locais deprimidos da parte ocidental da área urbana, abrigado do fluxo subsidente, foi arrefecendo normalmente ao longo da noite, por irradiação, donde tão acentuados contrastes térmicos espaciais.

\section{Conclusão}

Os resultados apresentados neste estudo mostram claramente que a magnitude e a fisionomia da ilha de calor de Coimbra variam em função das condições de tempo.

Nos dias com condições de tempo perturbado, os contrastes térmicos espaciais são atenuados e a ilha de calor restringe-se à "Baixa", em função do efeito de abrigo determinado pelas características da morfologia urbana e pela topografia, e em relação com a intensidade do trânsito.

Com condições de tempo anticiclónico, em que durante a tarde sopra "nortada" moderada, a ilha de calor aparece ligeiramente reforçada, atingindo $+3^{\circ} \mathrm{C}$ no núcleo principal, e expande-se da "Baixa" até Celas. Por vezes, aparecem núcleos secundários, com uma magnitude que pouco ultrapassa $+1^{\circ} \mathrm{C}$, centrados na Rua do Brasil, no Bairro Norton de Matos e na Av. Elísio de Moura.

Quando a "nortada" se faz sentir mais forte, a ilha de calor intensifica-se, atingindo $+4^{\circ} \mathrm{C}$, e o núcleo migra da sua posição habitual durante a tarde, da Av. Fernão de Magalhães para o vale da Av. Sá da Bandeira, em função das condições da abrigo aí criadas pela topografia. Para fora deste eixo quente, as temperaturas são significativamente inferiores e homogéneas entre os outros locais da cidade, onde o vento atenua os contrastes provocados pela ocupação urbana.
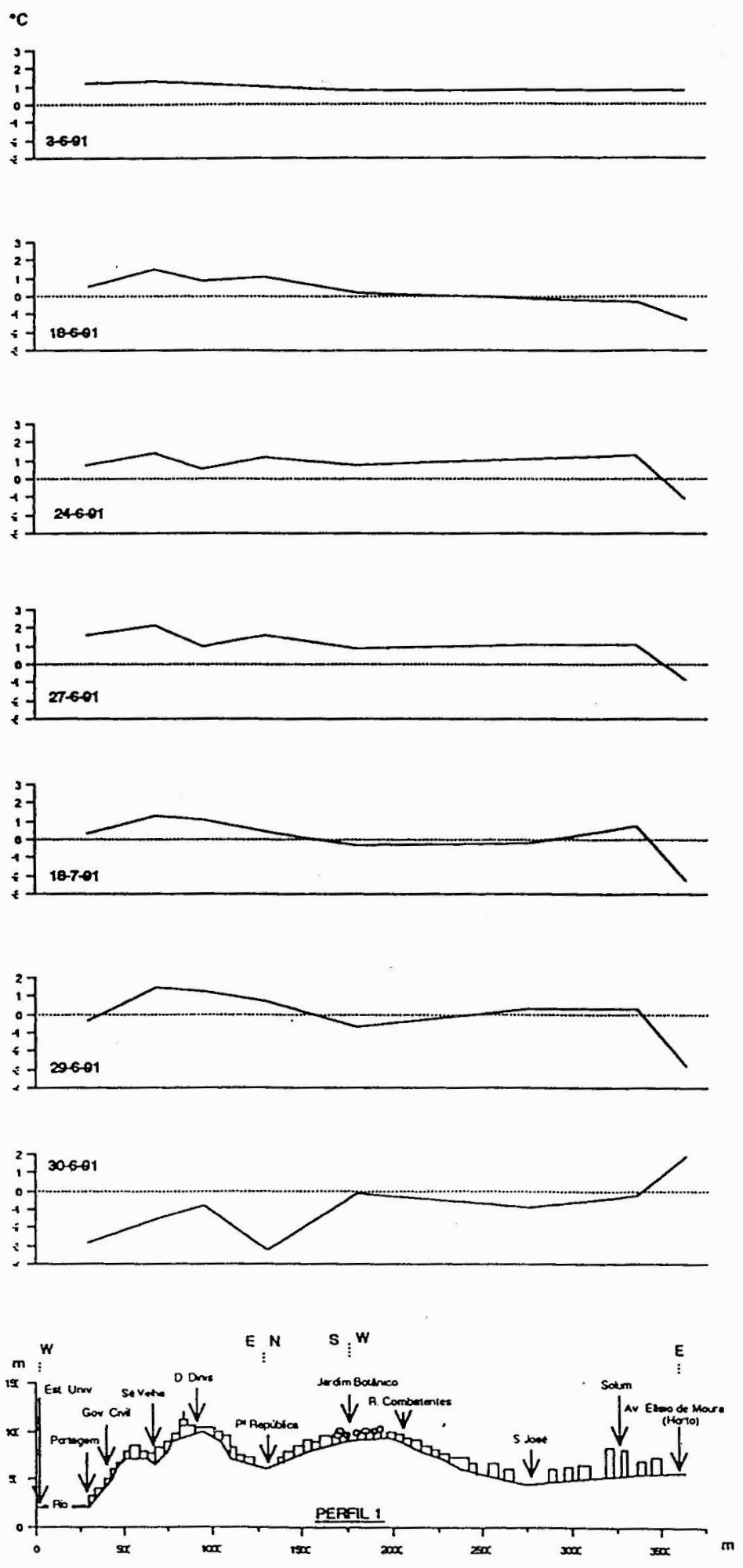

Fig. 22 - Perfis térmicos de temperaturas nocturnas relativas ao IGU $\left({ }^{\circ} \mathrm{C}\right)$ com condições de tempo anticiclónico. 
$\cdot \mathrm{C}$
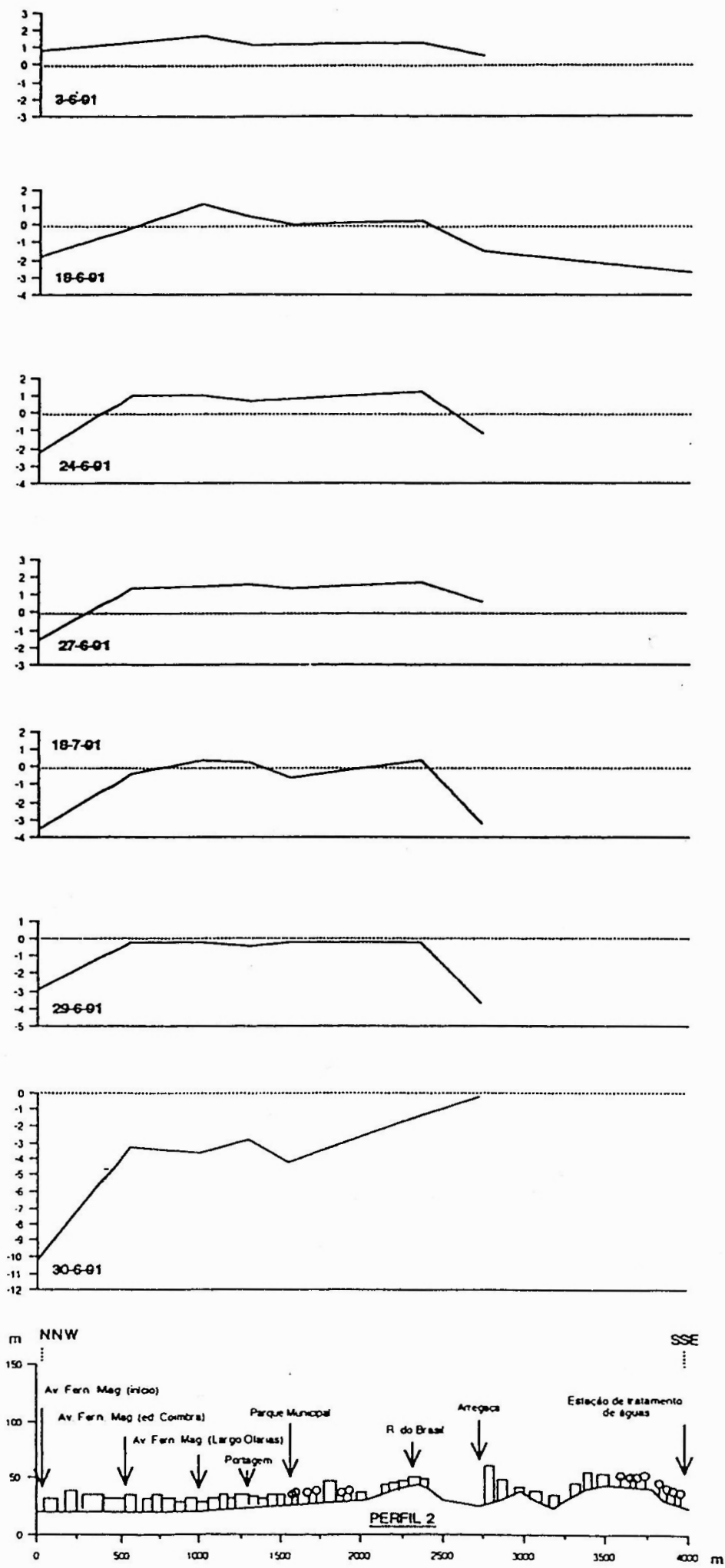

Fig. 23 - Perfis térmicos de temperaturas nocturnas relativas ao $I G U\left({ }^{\circ} \mathrm{C}\right) \mathrm{com}$ condições de tempo anticiclónico.
Nas raras situações estivais de vento fraco durante a tarde, o habitual núcleo da ilha de calor é substituído por uma "ilha de frescura", limitada às ruas estreitas da "Alta" e da "Baixa", como consequência da manifestação do efeito de sombra, que noutras condições é inibida pelos efeitos do vento, que se lhe sobrepõem.

Durante a noite, com condições de tempo perturbado, os contrastes térmicos espaciais são pouco sensíveis e a ilha de calor desdobrase em dois núcleos pouco intensos $\left(+1^{\circ} \mathrm{C}\right)$, restringidos aos locais mais baixos: um, englobando toda a área da "Baixa" até à Praça da República, e o outro ocupando o meandro da Arregaça, enquadrando os bairros de São José, Solum e Norton de Matos e a Quinta da Nora. Nos locais sobreelevados e desabrigados, as temperaturas igualam a do IGU.

Nas frequentes situações anticiclónicas de céu encoberto durante a noite, a repartição espacial da temperatura é semelhante à que se verifica com tempo perturbado. Os contrastes térmicos são fracos, a ilha de calor restringe-se à "Baixa" à "Alta" e, existindo algum vento, pode aparecer um outro núcleo na base da vertente setentrional do meandro da Arregaça, por conjugação do efeito de abrigo com a densidade de construção.

Com condições de tempo anticiclónico em que o céu permanece limpo durante a noite e madrugada, em que o vento é fraco e a humidade relativa elevada, a intensidade da ilha de calor excede os $3^{\circ} \mathrm{C}$, apresentando dois núcleos: o núcleo principal centrado na "Baixa e na "Alta", penetrando ao longo do vale da Av. Sá da Bandeira até à Praça da República, eum núcleo secundário englobando os bairros de São José, Solum e Norton de Matos. Por vezes, só se manifesta 0 núcleo principal; outras vezes, aparecem os dois núcleos, sendo o principal mais intenso; outras vezes ainda, ambos os núcleos apresentam igual intensidade.

Quando as condições de tempo são idênticas, mas o ar é seco, os contrastes térmicos espaciais aumentam e a magnitude da ilha de calor ultrapassa os 4 ou $5^{\circ} \mathrm{C}$. O núcleo principal permanece na mesma posição, mas a novidade é o aparecimento de um novo núcleo quente centrado na área de Celas, prolongando-se eventualmente para Santo António dos Olivais, relacionado também com o efeito urbano, mas reforçado pela posição topográfica sobreelevada. 
Com condições de tempo em que o vento sopra dos quadrantes de Leste durante a noite, ao efeito urbano sobrepõe-se o efeito do fluxo que subside ao longo das vertentes do Maciço Marginal e o efeito de abrigo relativamente a este, responsáveis por fortes contrastes térmicos entre os sectores oriental e meridional da cidade, mais quentes, $e$ os locais deprimidos, abrigados e arrefecidos, dos sectores setentrional e ocidental. Nestes casos a ilha de calor é destruída e o campo de temperaturas é determinado pela topografia, que transcende a influência urbana.

\section{BIBLIOGRAFIA}

ALCOFORADO, M. J. (1986) - "Contribution to the study of Lisbon's heat island". Freiburger Geographishe Hefte, Freiburg, pp. 165-176.

ALCOFORADO, M. J. (1988) - O Clima da Região de Lisboa - Vento, insolação e temperatura. Dissertação de Doutoramento em Geografia Física apresentada à Faculdade de Letras da Universidade de Lisboa, Lisboa 568p. (Policopiado).

ALCOFORADO, M. J. (1992) - O Clima da Regiäo de Lisboa - Contrastes e ritmos térmicos. C.E.G., Lisboa, 347p.

BIROT, P. (1949) - "Les surfaces d'érosion du Portugal Central et Septentrional". Rapport de la Comission pour la Cartographie des Surfaces d'Aplanissement, Louvain, U.G.I., pp. 9-116.

CARRERAS, C.;MARÍN, M.; VIDE, J.M.;MORENO, M. C.;SABÍ, J. (1990) - "Modificacionestérmicas en las ciudades. Avance sobre la isla de calor en Barcelona". Documents d'Anàlise Geogràfica, 17, pp. 51-77.

CHANDLER, T.J. (1962) - "London"s urban climate". The Geographical Journal, 128, 3, pp 279-302.

ESCOURROU, G. (1991) - Le Climat et la Ville. Nathan, Paris, $190 \mathrm{p}$.

GANHO, N. (199l) - "Contribuição para o conhecimento dos tipos de tempo de Verão em Portugal - o exemplo de Coimbra". Cadernos de Geografia, 10, Coimbra, I.E.G., pp. 431-513.

GANHO, N. (1992a) - O clima urbano de Coimbra Aspectos térmicos estivais. Dissertação de Mestrado em Geografia apresentada à Faculdade de Letras da Universidade de Coimbra, 170 p. + 80 p. extra texto de gráficos e figuras.
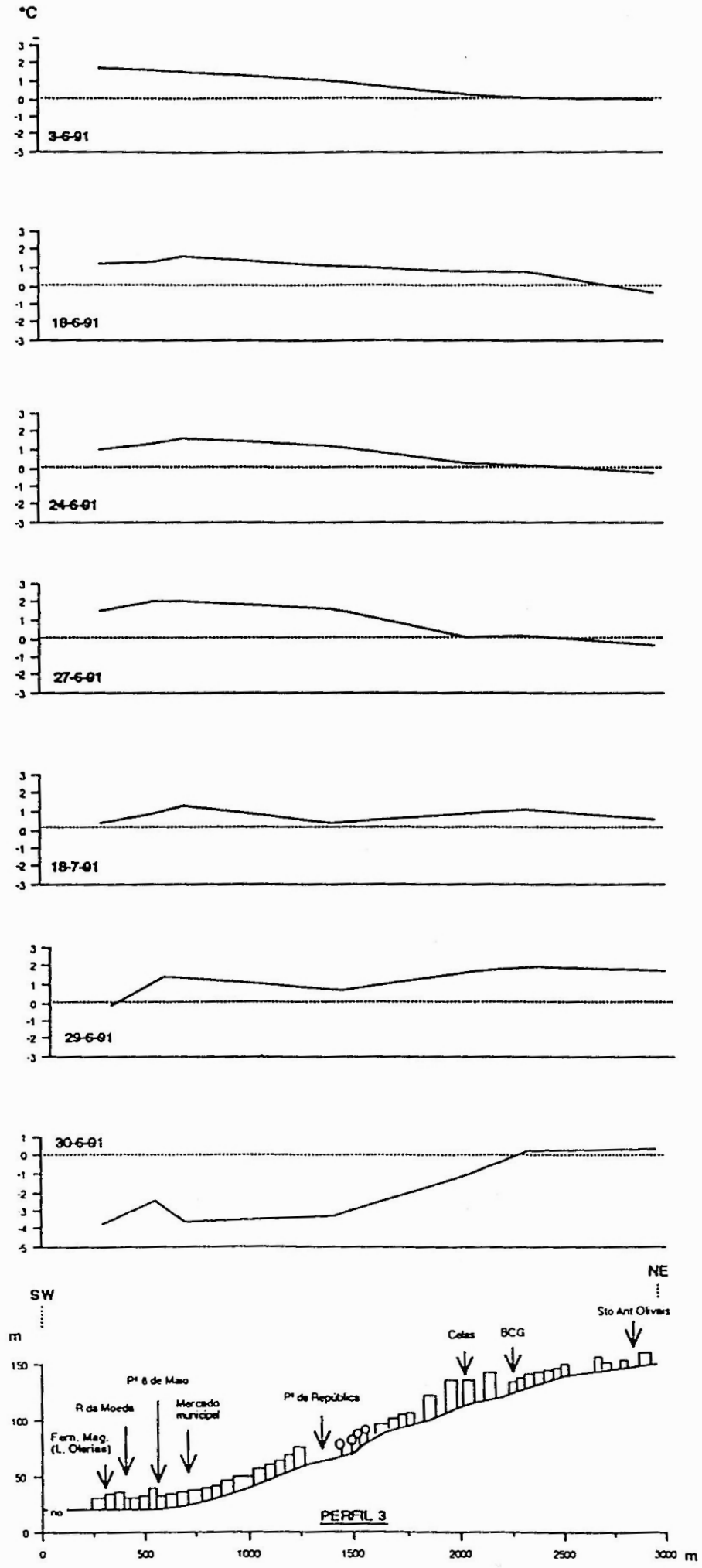

Fig. 24 - Perfis térmicos de temperaturas nocturnas relativas ao IGU $\left({ }^{\circ} \mathrm{C}\right)$ com condições de tempo anticiclónico. 
GANHO, N.(1992b) - "A ilha de calor de Coimbra - resultados de observações itinerantes de temperatura no interior do tecido urbano". Actas do VI Colóquio Ibérico de Geografia, Porto, 14 a 17 de Setembro de 1992 (em publicação).

GANHO, N. (1992c) - "Encontro de Climatologia e Hidrologia Urbanas". Biblos, 68, pp. 679-680.

GANHO, N. (1994a) - "Risco de incêndio florestal em áreas urbanas e periurbanas - o exemplo de Coimbra". Actas do II EPRIF-Encontro Pedagógico Sobre Risco de Incêndio Florestal, Coimbra, pp. 97-116.

GANHO, N. (1994b) - "A ilha de calor de Coimbra: intensidade média e ritmo diário - Resultados de observações com termohigrógrafos em abrigo". Actas do II Congresso da Geografia Portuguesa, Coimbra (em publicação).

GANHO, N. (?) - "La isla de calor de Coimbra bajo diferentes condiciones de tiempo de verano". Estudios Geográficos, Madrid (em publicação).

GEIGER, R. (1980) - Manual de Microclimatologia. O clima da camada de ar junto ao solo (trad. port. da $4^{\mathrm{a}}$ ed., 1961). Fundação Calouste Gulbenkian, Lisboa, 556 p.

HOWARD, L. (1818) - The climate of London. Longman, Londres.

LANDSBERG, H. E. (1981) - The Urban Climate. International Geophysics Series, vol. 28, Academic Press, 277 p.

LÓPEZGÓMEZ, A.; FERNÁNDEZ GARCÍA, F. (1984) - "La isla de calor en Madrid. Avance de un estudio de clima urbano". Estudios Geográficos, 174, pp. 5-34.

LÓPEZ GÓMEZ, A.; FERNÁNDEZ GARCÍA, F.; MORENO JIMÉNEZ, A.; PALOU, F. (1990) - "La temperatura diurna en la aglomeración de Madrid mediante imágenes remotas". Estudios Geográficos, 201, pp. 705-731.
LÓPEZ GÓMEZ, A; LÓPEZ GÓMEZ, J.; FERNÁNDEZ. GARCÍA,F.; ARROYO ILERA, F. (1991) - El Clima Urbano de Madrid: La Isla de Calor. C.S.I.C., Madrid, 166 p.

MONTEIRO, A. (1993) - O Clima Urbano do Porto - Contribuição para a definição das estratégias de planeamento $e$ ordenamento do território. Dissertação de Doutoramento em Geografia Física apresentada à Faculdade de Letras da Universidade do Porto, Porto, 436p.

MORENO, M. C. (1990) - "Bibliografía sobre Climatología urbana: la isla de calor, I.". Revista de Geografia, 24, pp. 99. 109.

OKE, T. R. (1987) - Boundary Layer Climates ( $2^{\mathrm{a}}$ edição). Routledge, London, 435p.

PÉDELABORDE, P. (1982) - Introduction a l'Étude Scientifique $d u$ Climat. Paris, S.E.D.E.S., 353 p.

RAMOS, C. (1986) - Tipos de anticiclones e ritmo climático de Portugal. Estudo de Climatologia. Linha de Acção de Geografia Física, C.E.G., rel. n² 25, Lisboa, 236 p.

RAMOS, C. (1987) - "A influência das situações anticiclónicas no regime da precipitação em Portugal". Finisterra, 22 (43), pp. $5 \cdot 38$.

REBELO, F. (1985) - "Nota sobre o conhecimento geomorfológico da área de Coimbra (Portugal)". Memórias e Noticias, Pub. Mus. Lab. Mineral. Geol. Univ. Coimbra, 100, pp. 193-202.

RUIZ, J. M. G. (1989) - "Organizacion espacial de las temperaturas en la ciudad de Logroño". Cuadernos de Investigacion Geografica, 15, 1-2, pp. 87-98. 